\title{
40. NEOGENE CONTROLS ON HYDROTHERMAL ACTIVITY AND PALEOCEANOGRAPHY OF THE SOUTHEAST PACIFIC OCEAN ${ }^{1}$
}

\author{
David K. Rea, Department of Atmospheric and Oceanic Science, The University of Michigan \\ and \\ Margaret Leinen, Graduate School of Oceanography, The University of Rhode Island ${ }^{2}$
}

\begin{abstract}
The Glomar Challenger crossed the East Pacific Rise at $19^{\circ} \mathrm{S}$ on Leg 92 during the austral fall of 1983 . The intent of the cruise was to recover sediments and rocks that would reveal the geologic history of seafloor hydrothermal activity as determined by the geochemistry and sedimentation history of hydrothermal material, the advection of sediment pore waters, the nature and history of alteration of seafloor basalt, and the paleoceanography of the southeast Pacific.

Results show that the composition of hydrothermal material is determined by its source and modified by exposure to seawater during transport in the water column. The flux of hydrothermal sediment appears to increase during episodes of tectonic activity and ridge jumps but to be independent of spreading rate. Pore water advection in sediment may occur early in the depositional history of a site, but it does not appear to continue for more than 1 or 1.5 m.y.

The basaltic rocks recovered are mostly low-olivine tholeiites, but those recovered at two sites contain ferrobasalt and alkali basalt. Hole 597C is the deepest penetration by the Deep Sea Drilling Project of fast-spreading crust. Basalts from that hole reveal three stages of alteration: an early deuteric stage, a reducing stage, and a later oxidative stage. K/ Ar dates of alteration minerals suggest that alteration continues for 9 to $15 \mathrm{~m}$.y. after the formation of crust.

Paleoceanographic studies have defined the Neogene history of the compensation depth and lysocline, the timing of important changes in atmospheric transport processes, and the nature and age of significant intervals of reworking in the abyssal sediments.
\end{abstract}

\section{INTRODUCTION}

Investigations of hydrothermal activity at mid-ocean ridge crests over the last $10 \mathrm{yr}$. have demonstrated that a major geochemical exchange process takes place as seawater enters fractures and fissures formed by the cooling of fresh ridge crest basalt and reacts with the hot basalt at temperatures in excess of $300^{\circ} \mathrm{C}$ (e.g., Edmond et al., 1979; von Damm et al., 1983). Further, but lower temperature, alteration of the basalt takes place on the flanks of mid-ocean ridges, where seawater circulating through the sediment column and into fractures in the partially cooled basalt reacts at temperatures of $<60^{\circ} \mathrm{C}$ (Bender, 1983; Maris and Bender, 1982; Bender et al., in press). The chemical exchanges that occur during these processes include the removal of magnesium and sulfate from seawater and the concomitant enrichment of the hydrothermal solutions in calcium, potassium, silica, iron, manganese, and trace elements. Although the magnitudes of the hydrothermal fluxes are still poorly known, it is clear from the chemistry of the hydrothermal fluids that the fluxes of some elements involved in hydrothermal activity, like magnesium, are of the same order of magnitude as river inputs and thus of equivalent importance in oceanic chemical budgets. Potential changes in these fluxes through time are therefore important variables in both conceptual and quantitative models of the

\footnotetext{
${ }^{1}$ Leinen, M., Rea, D. K., et al., Init. Repts. DSDP, 92: Washington (U.S. Govt. Printing Office).

2 Addresses: (Rea) Oceanography Program, Department of Atmospheric and Oceanic Science, The University of Michigan, Ann Arbor, MI 48109; (Leinen) Graduate School of Oceanography, The University of Rhode Island, Narragansett, RI 02882-1197.
}

paleochemistry and geochemical cycles of the ocean. For these reasons it is important to constrain possible changes in the extent or intensity of hydrothermal activity through time. It has been argued that such changes could affect the composition, sedimentation rates, and productivity of the oceans, and that they could have farreaching effects on climate (e.g., Corliss et al., 1979; Heath and Dymond, 1981; Rona et al., 1984; Owen and Rea, 1985). The present-day distribution of the precipitates from hydrothermal solutions suggests that hydrothermal activity may vary directly with the rate of seafloor spreading (Boström, 1974); if such a correlation exists, changes in hydrothermal activity may be proxy indicators of changes in ridge crest volume through time.

Because the present sampling of oceanic crust is incomplete, changes in hydrothermal activity must be inferred from evidence of the output of the hydrothermal systems, like changes in the amount and chemistry of iron-oxide-rich hydrothermal sediment precipitating from the hydrothermal solutions and changes in the composition of phases formed in equilibrium with seawater such as biogenic calcite. Previous studies of the Cenozoic rates of accumulation of hydrothermal sediments in the South Atlantic (Boström et al., 1972) and eastern Pacific (Leinen and Stakes, 1979; Leinen, 1981) suggested that changes by factor of 5 have taken place in hydrothermal sediment deposition in the past. None of the studies of hydrothermal sediments had the appropriate samples to examine the temporal output of a single segment of ridge crest, however; these studies were therefore unable to rule out the possibility that the changes observed in hydrothermal sediment deposition were due to local differences in activity along a ridge crest. Conflicting evidence 
of the importance of changes in hydrothermal activity comes from the $\mathrm{Li} / \mathrm{Ca}$ ratio of foraminiferal calcite during the Cenozoic, which indicates no significant change in the global rate of hydrothermal activity (Delaney, 1982). However, the interpretation of the $\mathrm{Li} / \mathrm{Ca}$ ratios is complicated by the diverse response of $\mathrm{Li}$ in hydrothermal systems (Seyfried et al., 1984), and Graham et al. (1982) have determined that the $\mathrm{Sr} / \mathrm{Ca}$ ratios of Cenozoic foraminifers show changes in global hydrothermal activity.

\section{Leg 92 Drill Site Selection}

The primary purpose of Leg 92 was to determine the nature and geologic history of basalt-seawater (hydrogeology) interactions at a single segment of the East $\mathrm{Pa}-$ cific Rise (EPR) and to evaluate the importance of offaxis hydrothermal activity on its flanks. To achieve these objectives a series of areas west of the EPR crest at $19^{\circ} \mathrm{S}$ (Fig. 1) were surveyed for drill sites by the Thomas Washington (cruise Ariadne II; Lonsdale, this volume; Leinen and Graybeal, this volume) in February and March of 1982. The transect was placed at $19^{\circ} \mathrm{S}$ for several reasons. First, the portion of the East Pacific Rise which lies between the triple junctions at $2^{\circ} \mathrm{N}$ and $35^{\circ} \mathrm{S}$, is the fastest-spreading portion of the world's rift system, with whole rates of accretion of 151 to $162 \mathrm{~mm} / \mathrm{yr}$. (Rea, 1981). High spreading rates appear to have been characteristic of this region throughout the Cenozoic (Handschumacher, 1976), so the rate of hydrothermal deposition, if it is indeed related to spreading rate, should have been high throughout that time. Second, the tectonic history of the East Pacific Rise is well enough known (Herron, 1972; Handschumacher, 1976; Rea, 1978a; Mammerickx et al., 1980) so that the tectonic parameters associated with spreading-rate variations and possible changes in hydrothermal activity can be evaluated.
An additional reason that the East Pacific Rise is the preferred location for this temporal study of hydrothermal activity is that the details of the history of volcanism, and to a lesser extent the changes in spreading rate, are reasonably well understood. This information makes it possible to test the hypothesis that fluctuations in hydrothermal activity are correlated with known changes in spreading rate and/or volcanic output. Kennett et al. (1977) have demonstrated that circum-Pacific volcanism has a Neogene periodicity of $5 \mathrm{~m}$.y. Major pulses of volcanic extrusion occurred 14 to $16 \mathrm{Ma}$ and during the last $1 \mathrm{~m} . \mathrm{y}$. Lesser pulses occurred 8 to 11 and 4 to $6 \mathrm{Ma}$ (Kennett et al., 1977). Rea and Scheidegger (1979) showed that the same periodicity characterizes extrusion rates along the Hawaiian Ridge, a correlation that suggests that plate-margin and mid-plate volcanic activity vary in concert. Available data further suggest that, in the east Pacific, times of heightened volcanic activity coincide with times of increased spreading rate (Rea and Scheidegger, 1979).

All of the above considerations suggested that the sediments from the EPR at $19^{\circ} \mathrm{S}$ would have a strong signal of hydrothermal activity that could be interpreted within a reasonable tectonic and geologic framework. However, the nature of the sediments accumulating along with the hydrothermal phases also constrains the resolution with which changes in hydrothermal input can be determined. Thus, the final reason that the $19^{\circ} \mathrm{S}$ transect was chosen for a study of the history of hydrothermal activity is that sediments of the southeast Pacific are dominated by only two components: biogenic calcium carbonate and the hydrothermal component. The hydrothermal component consists of poorly crystalline iron and manganese oxides and oxyhydroxides, poorly crystalline clays and goethite formed by the diagenesis

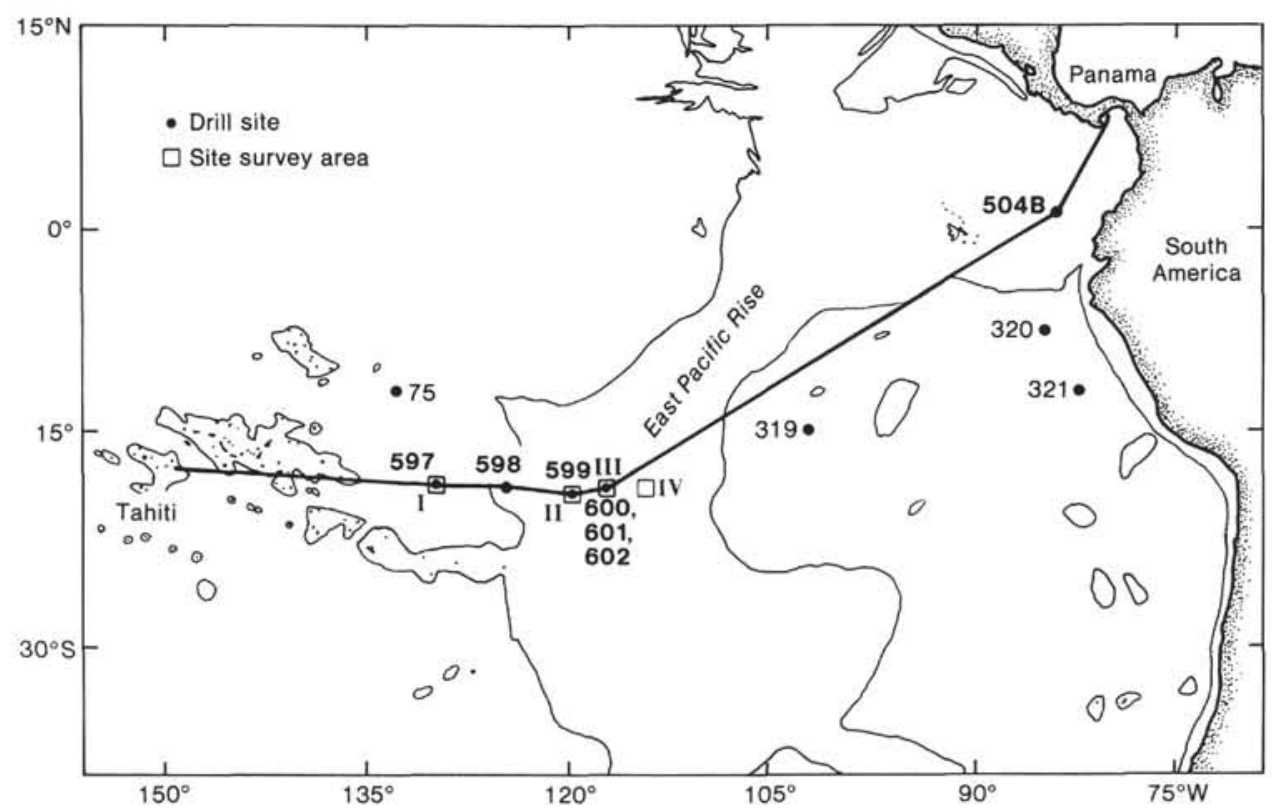

Figure 1. Index map of the south Pacific showing Leg 92 track line, site survey Areas I to IV, Leg 92 drill sites, and other sites used to construct subsidence history of calcite compensation depth. 
of the oxides, and red brown yellow brown semiopaque oxides (RSOs; Quilty et al., 1976). RSOs appear to be amorphous diagenetic oxide products. The other sedimentary components normally found in deep-sea sediments (terrigenous detritus, biogenic silica [opal], and hydrogenous [authigenic] zeolites and manganese oxides) are present in very small amounts or are absent altogether. Volcanic glass, diagenetic products such as barite, and other common constituents of slowly accumulating sediments such as apatitic fish debris are also present in only trace quantities. The sedimentation rates in the region are some of the lowest in the world ocean, on the order of a few millimeters per thousand years. In combination, these sedimentary characteristics suggested that the hydrothermal signal in this region should be strong and should not be masked by other sedimentary components or extensively altered by diagenesis.

\section{Study Objectives}

The objectives of this study of past ridge axis and present ridge flank hydrothermal activity were as follows:

1. To determine the Neogene history of hydrothermal activity in the southeast Pacific and thus test the hypothesis that hydrothermal activity varies directly with rates of spreading and/or volcanic extrusion; and to determine whether the composition of hydrothermal sediments has changed with time.

2. By sampling the interstitial waters in sediments from differing heat-flow environments and sediment thicknesses on the ridge flank, to determine whether pore water advection is or has been occurring; and to examine the sediments for evidence of alteration by ridge flank hydrothermal solutions.

3. By drilling a re-entry hole into older crust formed at a fast-spreading ridge, to study the nature, sequence, and possibly the timing of hydrothermal alteration.

4. By re-entering Hole 504B, to (a) investigate the previously documented downhole flow of water into the underpressured zone in Layer $2 \mathrm{~A}$; (b) determine the chemistry of waters equilibrating with the hole over the 15 mo. since the Leg 83 drilling; and (c) conduct downhole experiments to determine the near- and far-field physical properties of the oceanic crust around the hole. (This work is summarized in the Site 504 chapter, this volume.)

\section{Tectonic Setting of Leg 92 Drill Sites}

During the Paleogene the ancestral EPR formed the boundary between the Pacific and Farallon plates. The ensuing segmentation of the Farallon Plate, caused by the collision of North America and the northern portion of the EPR system, resulted in the rearrangement of spreading centers in the east Pacific and the formation of the Nazca and Cocos plates. In the south Pacific, this rearrangement occurred as a series of ridge jumps, usually from east to west, that abandoned old spreading axes and created the modern EPR (Fig. 2). South of the Garrett Fracture Zone at $13^{\circ} \mathrm{S}$, the westward shift of spreading activity from the fossil Mendoza and Roggeveen rises to the present EPR occurred during the early Miocene; the estimated age of these jumps is 18.4 to 20
Ma (Mammerickx et al., 1980). North of the Garrett Fracture Zone, spreading activity at the fossil Galapagos Rise shifted west in a series of three jumps that occurred between about 8.2 and $5.7 \mathrm{Ma}$ (Rea, 1978a). The geologic configuration resulting from this sequence of ridge jumps is such that on Leg 92 the Glomar Challenger drilled holes on lithosphere generated both at the fossil Mendoza Rise (Site 597) and at the present EPR (Sites 598 to 602). Along our track line at $19^{\circ} \mathrm{S}$, the boundary between the older and younger lithosphere lies at the Austral Fracture Zone (Mammerickx et al., 1980; Rea, this volume). Seafloor magnetic anomalies along the Leg 92 track line are clear enough to be identified, thus enabling spreading rates to be calculated (Rea, this volume). Spreading half-rates for each drilling region are given in Table 1; they range from $55 \mathrm{~mm} / \mathrm{yr}$. at Site 597 to $84 \mathrm{~mm} / \mathrm{yr}$. at Sites 600 to 602 .

\section{REGIONAL SEDIMENTATION AS REFLECTED IN LEG 92 DRILL SITES}

Most sediments recovered from the Leg 92 drill sites (Table 2) are a mixture of nannofossil ooze and clay, commonly clay-bearing or clayey nannofossil ooze. The only other lithologies are a thin layer of unfossiliferous pelagic clay at the top of Site 597 and thin chalky layers immediately above basement at Site 598, 600, and 601 (Fig. 3). Foraminifers are rare to common in the calcareous sections but usually constitute less than $10 \%$ of the sediment. No siliceous microfossils were found. The clay component is almost entirely of hydrothermal origin and consists of poorly crystalline iron and manganese oxides and oxyhydroxides; RSOs, which in the Leg 92 sediments are dominantly goethite; and poorly crystalline clays formed by the diagenesis of the hydrothermal oxides.

The sediments are much like those of Site 75 to the northwest (Fig. 1), but the sedimentary sections are thinner for equivalent ages. The nannofossil and foraminiferal assemblages are also very similar to those found at Site 75 , and the similarity suggests that the sedimentary record for the Neogene and late Paleogene at the Leg 92 drill sites may be representative of much of the subtropical south Pacific.

The upper parts of the sections at Sites 597, 598, and 599 are compressed because the sediments were accumulating beneath the lysocline. There is therefore little overlap between the higher-sedimentation-rate portions of each site. Site 601 contains the best record of Pliocene to Pleistocene sedimentation, Site 598 contains the best record of middle to late Miocene sedimentation, and Site 597 contains the only record of early Miocene and late Oligocene sedimentation. Taken together, however, the transect sites represent south Pacific sedimentation over the last 28.6 m.y. and can be used to infer sedimentation histories for that time interval. The average sedimentation rates for the lower parts of the sections each site are 3 to $8 \mathrm{~m} / \mathrm{m}$.y., whereas the rates for the upper parts of the sections are about 0.1 to $2 \mathrm{~m} / \mathrm{m}$.y. (Table 3 ). The linear sedimentation rates indicated by the biostratigraphy can be combined with values of dry-bulk density estimated from the sediment porosity to give sediment mass 


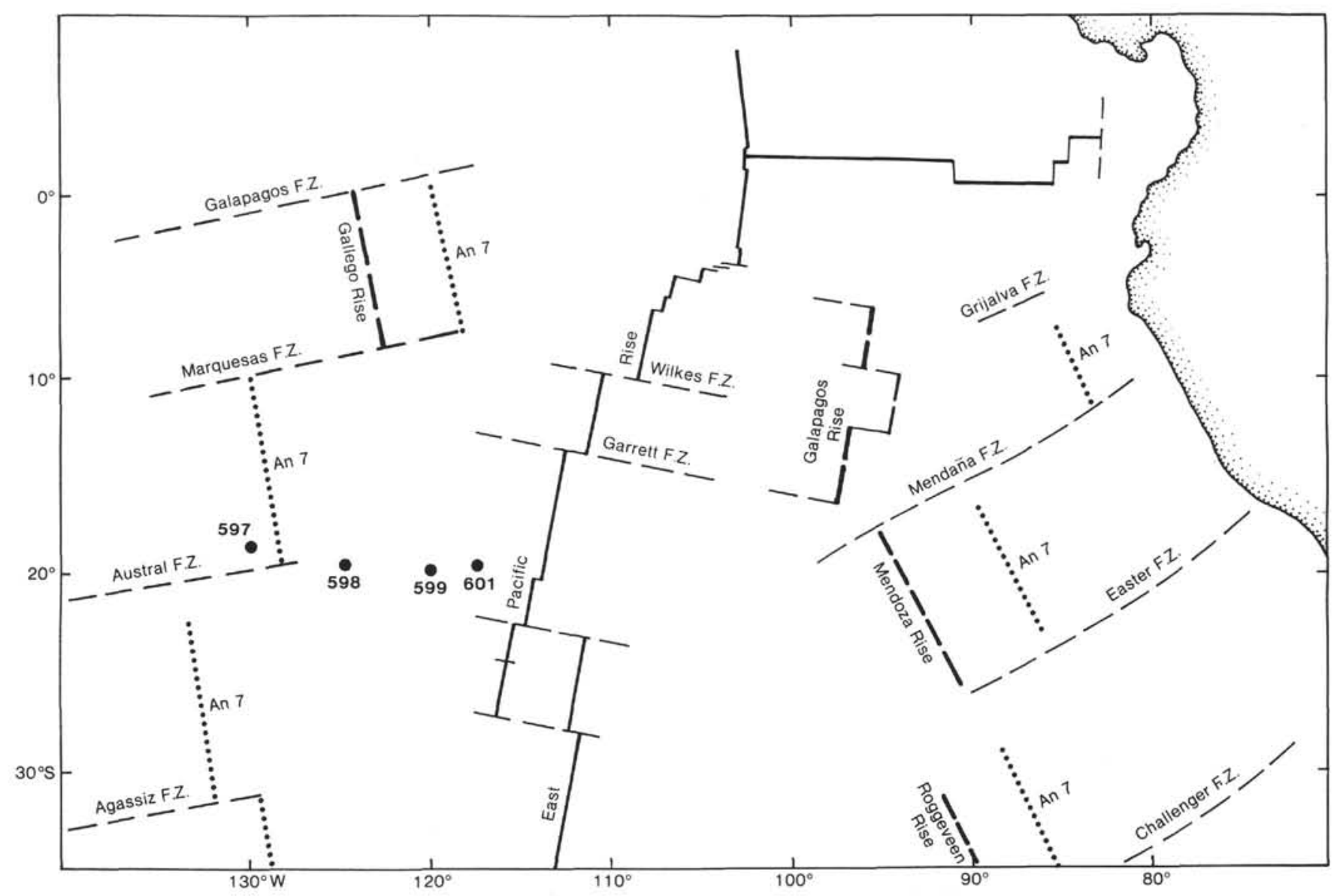

Figure 2. Major topographic and structural features of the southeast Pacific. Heavy solid lines are active spreading ridges. Heavy dashed lines are abandoned spreading ridges; dotted lines locate Anomaly 7 (26 Ma isochron); dashed lines are fracture zones (from Mammerickx et al., 1980).

Table 1. Seafloor spreading rates along the Leg 92 track line. Anomaly nomenclature and time scale are from Harland et al. (1982).

\begin{tabular}{lcccc}
\hline & $\begin{array}{c}\text { Spreading rate for } \\
\text { interval with } \\
\text { site in center } \\
(\mathrm{km} / \mathrm{m} . \mathrm{y} .)\end{array}$ & $\begin{array}{c}\text { Anomalies } \\
\text { bounding } \\
\text { intervals }\end{array}$ & $\begin{array}{c}\text { Anomaly } \\
\text { age of } \\
\text { basement } \\
(\mathrm{Ma})\end{array}$ & $\begin{array}{c}\text { Rate between } \\
\text { drill sites } \\
(\mathrm{km} / \mathrm{m} . \mathrm{y} .)\end{array}$ \\
\hline 597 & 55.4 & Young edge 12, young edge 7 & 28.6 & a \\
598 & $\mathrm{~b}_{57.8}$ & Old edge 5B.1, young edge 5A.1 & 16.0 & 61.2 \\
599 & 73.3 & Young edge 5A.1, old edge 3A & 7.8 & 93.1 \\
$600-602$ & 84.0 & Old edge 3A, young edge 2A & 4.6 & 75.6 \\
Axis & $\mathrm{C}_{70.4 / \mathrm{d}_{66.5}}$ & & 0 & \\
\hline
\end{tabular}

a Discontinuity at Austral Fracture Zone; see text.

b From anomalies younger than site only.

${ }_{\mathrm{d}}^{\mathrm{c}}$ From $20^{\circ} \mathrm{S}$ survey area (Rea, 1978b).

accumulation rates (in $\mathrm{mg} /\left[\mathrm{cm}^{2} \times 10^{3} \mathrm{yr}\right.$.]) for the sediment columns (Table 3 ). The biogenic pelagic sediments of the Leg 92 transect clearly reflect deposition from oligotrophic waters. The organic carbon contents of the sediments are very low ( 0.2 to 0.4 wt. $\%$; Kastner, this volume), and the hydrocarbons in the sediments are dominantly land derived, probably eolian (Meyers et al., this volume). Pore water nutrient profiles (Bender et al., in press) indicate that the sediments are highly oxidized and have received little organic material. No siliceous microfossils are preserved in the sediments. The concentra- tions of barite and other refractory phases indicative of biogenic silica (opal) and carbonate dissolution (Leinen and Graybeal, this volume) are also low, an indication that the low biogenic sediment accumulation rates are not the result of the dissolution of a large biogenic input.

\section{History of Calcite Deposition, Calcite Compensation Depth, and Lysocline}

The lower portions of the cores at Sites 597, 598, and 599 are all characterized by moderately high carbonate content ( 75 to $85 \%$ ), which increases upcore to 85 to $95 \%$ (Fig. 4). This increase reflects the sites' moving away from the rise crest; at the rise crest, the carbonate is diluted by hydrothermal sediments (Lyle, this volume; Leinen, this volume). At each of these sites, all of which presently lie beneath the lysocline (Rea and Leinen, this volume), a decrease in carbonate content and/or accumulation rate is associated with the time at which the site sank beneath the lysocline. At Site 597, which has been below the lysocline the longest, the upper $1.4 \mathrm{~m}$ of sediment are noncalcareous.

Plotting the depth-time history of calcite accumulation at the Leg 92 and other south Pacific drill sites defines the Neogene history of the calcite compensation depth (CCD) and the lysocline in this area (Fig. 5; and Rea and Leinen, this volume). The CCD shoaled from $4200 \mathrm{~m}$ to $3700 \mathrm{~m}$ between 24 and $20 \mathrm{Ma}$, then deepened 
Table 2. Leg 92 coring summary.

\begin{tabular}{|c|c|c|c|c|c|c|c|c|c|}
\hline Hole & $\begin{array}{c}\text { Dates } \\
\text { (Mar. 1983) }\end{array}$ & $\begin{array}{l}\text { Latitude } \\
\text { (S) }\end{array}$ & $\begin{array}{c}\text { Longitude } \\
\text { (W) }\end{array}$ & $\begin{array}{c}\text { Water } \\
\text { depth } \\
\text { (m) }\end{array}$ & $\begin{array}{l}\text { Penetration } \\
\text { (m) }\end{array}$ & $\begin{array}{c}\text { Number of } \\
\text { cores }\end{array}$ & $\begin{array}{l}\text { Cored } \\
\text { interval } \\
\text { (m) }\end{array}$ & $\begin{array}{l}\text { Recovery } \\
\text { (m) }\end{array}$ & $\begin{array}{c}\text { Recovery } \\
(\%)\end{array}$ \\
\hline 597 & $2-3$ & $18^{\circ} 48.38^{\prime}$ & $129^{\circ} 46.23^{\prime}$ & 4166.5 & 54.7 & 8 & 54.7 & 42.1 & 77.0 \\
\hline $597 \mathrm{~A}$ & $3-4$ & $18^{\circ} 48.43^{\prime}$ & $129^{\circ} 46.22^{\prime}$ & 4162.6 & 48.6 & 6 & 45.0 & 42.9 & 95.0 \\
\hline 597B & $5-6$ & $18^{\circ} 48.43^{\prime}$ & $129^{\circ} 46.22^{\prime}$ & 4162.6 & 72.6 & 3 & 24.6 & 5.43 & 22.0 \\
\hline $597 \mathrm{C}$ & $7-15$ & $18^{\circ} 48.43^{\prime}$ & $129^{\circ} 46.22^{\prime}$ & 4164.0 & 143.5 & 12 & 100.0 & 55.21 & 55.2 \\
\hline 598 & $17-18$ & $19^{\circ} 00.28^{\prime}$ & $124^{\circ} 40.61^{\prime}$ & 3699.0 & 52.4 & 8 & 52.4 & 41.29 & 78.8 \\
\hline $598 \mathrm{~A}$ & $18-18$ & $19^{\circ} 00.28^{\prime}$ & $124^{\circ} 40.61^{\prime}$ & 3699.0 & 33.0 & 0 & 0 & 0 & 0 \\
\hline 599 & $20-21$ & $19^{\circ} 27.09^{\prime}$ & $119^{\circ} 52.88^{\prime}$ & 3654.0 & 40.8 & 5 & 40.8 & 34.76 & 85.0 \\
\hline $599 \mathrm{~A}$ & $21-21$ & $19^{\circ} 27.09^{\prime}$ & $119^{\circ} 52.88^{\prime}$ & 3654.0 & 22.6 & 0 & 0 & 0 & 0 \\
\hline 599B & $21-22$ & $19^{\circ} 27.09^{\prime}$ & $119^{\circ} 52.88^{\prime}$ & 3654.0 & 49.8 & 4 & 23.6 & 11.56 & 49.0 \\
\hline 600 & $23-24$ & $18^{\circ} 55.74^{\prime}$ & $116^{\circ} 50.37^{\prime}$ & 3346.0 & 10.4 & 2 & 10.4 & 5.38 & 51.7 \\
\hline $600 \mathrm{~A}$ & $24-24$ & $18^{\circ} 55.74^{\prime}$ & $116^{\circ} 50.37^{\prime}$ & 3346.0 & 9.6 & 1 & $9.6^{\mathrm{a}}$ & 0 & 0 \\
\hline $600 \mathrm{~B}$ & $24-24$ & $18^{\circ} 55.74^{\prime}$ & $116^{\circ} 50.37^{\prime}$ & 3346.0 & 1.9 & $i$ & 1.9 & 1.9 & 100.0 \\
\hline $600 \mathrm{C}$ & $24-25$ & $18^{\circ} 55.70^{\prime}$ & $116^{\circ} 50.45^{\prime}$ & 3398.0 & 19.0 & 2 & 19.0 & 11.8 & 62.1 \\
\hline 601 & $25-25$ & $18^{\circ} 55.22^{\prime}$ & $116^{\circ} 52.11^{\prime}$ & 3433.0 & 20.4 & 3 & 20.4 & 19.45 & 95.3 \\
\hline $601 \mathrm{~A}$ & $25-25$ & $18^{\circ} 55.22^{\prime}$ & $116^{\circ} 52.11^{\prime}$ & $3433.0^{\mathrm{b}}$ & 15.0 & 0 & 0 & 0 & 0 \\
\hline $601 \mathrm{~B}$ & $25-26$ & $18^{\circ} 55.22^{\prime}$ & $116^{\circ} 52.11^{\prime}$ & 3433.0 & 27.0 & 3 & 12.6 & 6.75 & 53.6 \\
\hline 602 & $26-27$ & $18^{\circ} 54.41^{\prime}$ & $116^{\circ} 54.68^{\prime}$ & 3535.0 & 6.2 & 1 & 6.2 & 6.19 & 99.8 \\
\hline $602 \mathrm{~A}$ & $27-27$ & $18^{\circ} 54.41^{\prime}$ & $116^{\circ} 54.68^{\prime}$ & 3535.0 & 2.3 & 1 & 2.3 & 2.28 & 99.1 \\
\hline $602 B$ & $27-27$ & $18^{\circ} 54.41^{\prime}$ & $116^{\circ} 54.68^{\prime}$ & 3535.0 & 4.2 & $i$ & 4.2 & 4.24 & 101.1 \\
\hline
\end{tabular}

a Core barrel left in hole.

by bit, water depth from PDR.

to near the present value $(4100 \mathrm{~m})$ by $5 \mathrm{Ma}$. The lysocline and the CCD were at similar depths before $20 \mathrm{Ma}$ but began to separate between 20 and $17 \mathrm{Ma}$. By $14 \mathrm{Ma}$, the lysocline had risen to $600 \mathrm{~m}$ above the $\mathrm{CCD}$, where it has remained. This change could reflect either the increase in the volume of Antarctic Bottom Water beginning 18 or $19 \mathrm{Ma}$ and reaching steady state by $14 \mathrm{Ma}$, or an increase in the calcite rain rate reflecting increased productivity of surface waters (Rea and Leinen, this volume).

\section{History of Eolian Sedimentation in the Subtropical South Pacific}

Windblown dust deposited in the oceans can provide a record of both the climate of the source area and the intensity of the zonal winds (Rea et al., 1985). The Leg 92 drill sites indicate that the flux of dust has been very low and relatively constant at 2 to $3 \mathrm{mg} /\left(\mathrm{cm}^{2} \times 10^{3} \mathrm{yr}\right.$. $)$ in the southeast Pacific since the late Oligocene. Only one major change occurs in the grain size of the dust, a coarsening from older sediments averaging $8.3 \phi$ to younger sediments averaging $7.2 \phi$. This size change occurs between 11.8 and 9.5 Ma (Bloomstine and Rea, this volume).

These data are interpreted as indicating a low and constant supply of dust to the south Pacific from South America and suggest that no major change in South American climate has taken place during the past $28 \mathrm{~m}$.y. and/or that orographic processes on the east flank of the Andes have always been able to wash out dust from the troposphere. The change in grain size provides evidence of an increase in trade wind intensity about 10.5 Ma. This date is fairly well determined and is 2 to $3 \mathrm{~m}$.y. younger than the age of formation of the Antarctic ice cap as based on oxygen isotope data (see discussion in Bloomstine and Rea, this volume).

An equally important observation is that the Southern Hemisphere Leg 92 drill sites contain no evidence in the eolian dust of any atmospheric response to the onset of Northern Hemisphere glaciation $2.5 \mathrm{Ma}$. At Northern Hemisphere sites this event is characterized by a 5to 10 -fold increase in the flux of dust to the oceans and a moderate increase in dust grain size. Taken together, the data indicate that atmospheric circulation in the Southern Hemisphere was generally more intense than that in the Northern Hemisphere and acted independently of the Northern Hemisphere in terms of its response to various polar cooling events (Bloomstine and Rea, this volume).

\section{Sediment Reworking at Site $\mathbf{5 9 9}$}

Sediments recovered from Core 3 at Site 599 exhibit evidence of reworking and downslope transport. Distinct dark and light layers, each tens of centimeters thick, occur in the core (Fig. 6). Contacts between lower lightcolored layers and overlying darker layers are all sharp. Contacts between lower dark layers and upper light layers are variable; some are sharp, some are gradational. The same color boundaries mark changes in the preservation of calcareous microfossils (Romine, this volume; Knüttel, this volume). Knüttel (this volume) reports that inversions of the normal nannofossil zonation sequence also occur at these contacts. Dark brown sediments with nannofossils of Zones CN8 and CN9a are intercalated with lighter-colored intervals which contain nannofossils of Zone CN9b (Fig. 7).

Rea and Janecek (this volume) performed grain-size analyses on bulk samples taken across the sharp color contacts. They showed that the darker-colored ooze, which is enriched in hydrothermal material, is, in all cases, coarser grained than the underlying lighter-colored ooze. The size changes range from $0.08 \phi$ to $0.88 \phi$ and average about $0.33 \phi$.

The sharp contacts, zonal inversions, and size changes all indicate that significant reworking occurred at this site during the late Miocene (5.4 to $6.7 \mathrm{Ma}$; nannofossil 

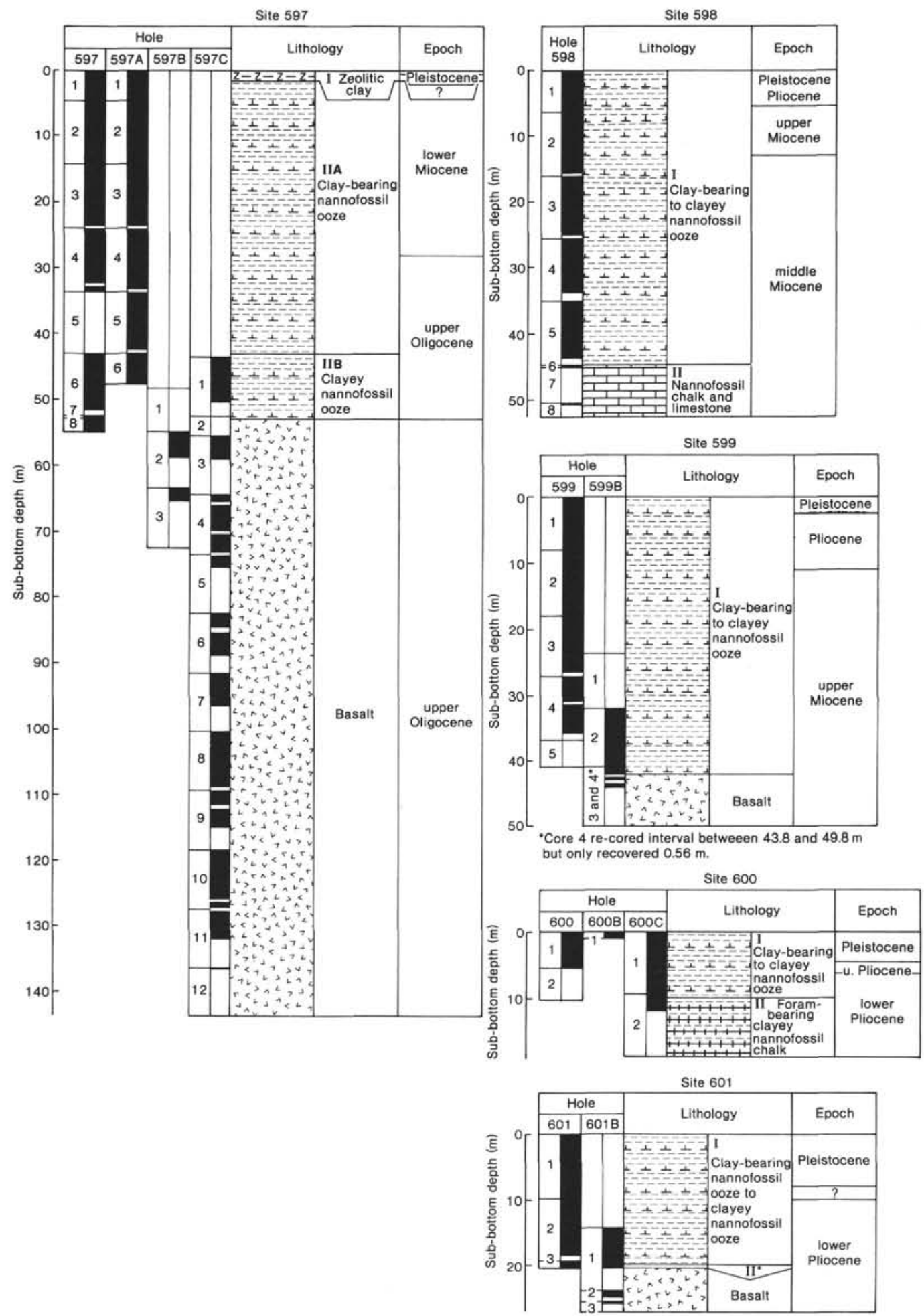

'Thin $(0.4 \mathrm{~m})$ unit (II) of clayey nannofossil chalk to nannofossil claystone

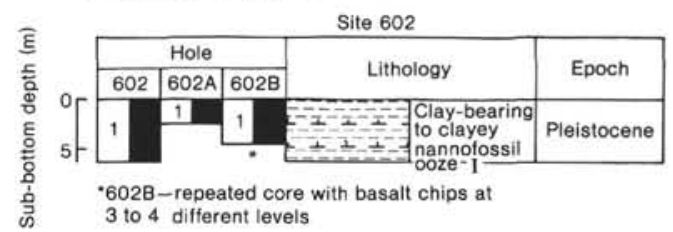

Figure 3. Lithology, age, and recovery of sediment and rock drilled at Sites 597 to 602 . 
Table 3. Summary of Leg 92 stratigraphy, sedimentation rates, and mass accumulation rates, calculated using Leg 92 zonation and newer stratigraphy from Berggren et al. (1985).

\begin{tabular}{|c|c|c|c|c|c|c|c|c|c|c|c|c|c|c|c|}
\hline $\begin{array}{l}\text { Sub-bottom } \\
\text { depth } \\
\text { (m) }\end{array}$ & $\begin{array}{c}\text { Starting } \\
\text { depth } \\
\text { (Core-Section, } \\
\text { level in } \mathrm{cm} \text { ) }\end{array}$ & $\begin{array}{c}\text { Ending } \\
\text { depth } \\
\text { (Core-Section, } \\
\text { level in } \mathrm{cm} \text { ) }\end{array}$ & $\begin{array}{l}\text { Vertical } \\
\text { change } \\
\text { (m) }\end{array}$ & $\begin{array}{l}\text { Nannofossil } \\
\text { zone }\end{array}$ & $\begin{array}{l}\text { Porosity } \\
(\%)\end{array}$ & $\begin{array}{c}\text { Dry-bulk } \\
\text { density } \\
\left(\mathrm{g} / \mathrm{cm}^{3}\right)^{\mathrm{a}}\end{array}$ & $\begin{array}{l}\text { Time } \\
\text { (m.y.) }\end{array}$ & $\begin{array}{l}\text { Change } \\
\text { in time } \\
\text { (m.y.) }\end{array}$ & $\begin{array}{r}\text { Line } \\
\text { sediment } \\
\text { rate } \\
(\mathrm{m} / \mathrm{m}\end{array}$ & $\begin{array}{l}\text { ar } \\
\text { tation } \\
\text { y.) }\end{array}$ & $\begin{array}{c}\text { Mass } \\
\text { accumulation } \\
\text { rate } \\
\left(\mathrm{mg} /\left[\mathrm{cm}^{2} \times 10^{3} \mathrm{yr} .\right]\right)\end{array}$ & $\begin{array}{l}\text { Time } \\
\text { (m.y.) }\end{array}$ & $\begin{array}{c}\text { Change } \\
\text { in time } \\
\text { (m.y.) }\end{array}$ & $\begin{array}{c}\text { Linear } \\
\text { sedimentation } \\
\text { rate } \\
(\mathrm{m} / \mathrm{m} . \mathrm{y} .)\end{array}$ & $\begin{array}{c}\text { Mass } \\
\text { accumulation } \\
\text { rate } \\
\left(\mathrm{mg} /\left[\mathrm{cm}^{2} \times 10^{3} \mathrm{yr} .\right]\right)\end{array}$ \\
\hline \multicolumn{7}{|l|}{ Hole 597} & \multicolumn{5}{|c|}{ Leg 92 zonations } & \multicolumn{4}{|c|}{ Zonations from Berggren et al. (1985) } \\
\hline $0-1.5$ & $1-1,150$ & $1-1,150$ & 1.5 & $<\mathrm{CN} 3 / 4$ & 80.7 & 0.511 & $0-14.2$ & 14.2 & 0.11 & & 5 & $0-14.2$ & 14.2 & 0.11 & 5 \\
\hline $1.5-4.1$ & $1-2,0$ & $1-3,110$ & 2.6 & $\mathrm{CN}_{3}+4$ & 70.8 & 0.774 & $14.2-17.0$ & 2.8 & 0.93 & & 72 & $14.2-17.2$ & 3.0 & 0.87 & 67 \\
\hline $4.1-15.5$ & $1-3,110$ & $3-1,130$ & 11.4 & $\mathrm{CN} 2$ & 61.3 & 1.026 & $17.0-18.7$ & 1.7 & 6.71 & & 688 & $17.2-19.0$ & 1.8 & 6.33 & 650 \\
\hline $15.5-19.2$ & $3-1,130$ & $3-4,50$ & 3.7 & $\mathrm{CNIc}$ & 58.0 & 1.113 & $18.7-22.0$ & 3.3 & 1.12 & & 125 & $19.0-22.2$ & 3.2 & 1.16 & 129 \\
\hline $19.2-27.8$ & $3-4,50$ & $4-3,100$ & 8.6 & $\mathrm{CNIa}+\mathrm{b}$ & 60.3 & 1.052 & $20.0-24.8$ & 2.8 & 3.07 & & 323 & $22.2-24.8$ & 2.6 & 3.31 & 348 \\
\hline $27.8-54.7$ & $4-3,100$ & Bottom & 26.9 & CP19b & 63.2 & 0.975 & $24.8-28.3$ & 3.5 & $\geq 7.69$ & & $\geq 750$ & $24.8-28.6$ & 3.8 & $\geq 7.08$ & $\geq 690$ \\
\hline \multicolumn{16}{|l|}{ Hole 598} \\
\hline $0-1.0$ & $1-1,0$ & $1-1,100$ & 1.0 & $<\mathrm{CN} 13-15$ & 77.4 & 0.599 & $0-1.88$ & 1.88 & 0.53 & & 32 & $0-1.88$ & 1.88 & 0.53 & 32 \\
\hline $1.0-4.7$ & $1-1,100$ & $1-4,20$ & 3.7 & CN10-12 & 74.8 & 0.668 & $1.88-5.40$ & 3.52 & 1.05 & & 70 & $1.88-5.40$ & 3.52 & 1.05 & 70 \\
\hline $4.7-6.4$ & $1-4,20$ & $2-1,20$ & 1.7 & CN9b & 66.6 & 0.885 & $5.4-6.7$ & 1.3 & 1.31 & & 116 & $5.4-6.7$ & 1.3 & 1.31 & 116 \\
\hline $6.4-9.0$ & $2-1,20$ & $2-2,130$ & 2.6 & CN9a & 67.8 & 0.853 & $6.7-8.1$ & 1.4 & 1.86 & & 159 & $6.7-8.1$ & 1.4 & 1.86 & 159 \\
\hline $9.0-12.4$ & $2-2,130$ & $2-5,20$ & 3.4 & $\mathrm{CN} 8 \mathrm{a}+\mathrm{b}$ & 67.9 & 0.851 & $8.1-9.2$ & 1.1 & 3.09 & & 263 & $8.1-9.2$ & 1.1 & 3.09 & 263 \\
\hline $12.4-16.0$ & $2-5,20$ & $3-1,20$ & 3.6 & $\mathrm{CN} 7 \mathrm{a}+\mathrm{b}$ & 66.6 & 0.885 & $9.20-10.7$ & 1.5 & 2.40 & & 212 & $9.2-12.0$ & 2.8 & 1.29 & 114 \\
\hline $16.0-17.0$ & $3-1,20$ & $3-1,120$ & 1.0 & CN6 & 68.5 & 0.835 & $10.7-12.0$ & 1.3 & 0.77 & & 64 & $12.0-12.5$ & 0.5 & 2.00 & 167 \\
\hline $17.0-29.7$ & $3-1,120$ & $4-3,130$ & 12.7 & CN5a + b & 72.4 & 0.731 & $12.0-14.2$ & 2.2 & 5.77 & & 422 & $12.5-14.2$ & 1.7 & 7.47 & 546 \\
\hline $29.7-52.4$ & $4-3,130$ & Bottom & 22.7 & $\mathrm{CN} 3-4$ & 74.8 & 0.668 & $14.2-17.0$ & 2.8 & 28.11 & & $\geq 542$ & $14.2-17.2$ & 3.0 & $\geq 7.57$ & $\geq 505$ \\
\hline \multicolumn{16}{|l|}{ Hole 599} \\
\hline $0-1.0$ & $1-1,0$ & $1-1,100$ & 1.0 & CN13-15 & 63.3 & 0.973 & $0-2.88$ & 1.88 & 0.53 & & 52 & & & & \\
\hline $1.0-2.8$ & $1-1,0$ & $1-1,130$ & 1.8 & CN11-12 & 64.0 & 0.954 & $1.88-3.70$ & 1.82 & 0.99 & & 94 & & & & \\
\hline $2.8-11.9$ & $1-2,130$ & $2-3,100$ & 9.1 & $\mathrm{CN} 10$ & 66.2 & 0.896 & $3.7-5.4$ & 1.70 & 5.357 & & 479) & & & & \\
\hline $11.9-30.8$ & $2-3,100$ & $4-3,70$ & 18.9 & $\mathrm{CN} 9 \mathrm{~b}$ & 70.8 & 0.774 & $5.4-6.7$ & 1.30 & 14.54 & 8,48 & $1125\} 657$ & & & No change & \\
\hline $30.8-34.8$ & $4-3,70$ & $4-6,20$ & 4.0 & CN9a & 70.7 & 0.776 & $6.7-8.1$ & 1.40 & 2.865 & 0,40 & $222 \int^{001}$ & & & & \\
\hline $34.8-40.8$ & $4-6,20$ & Bottom & 6.0 & $\mathrm{CN} 8 \mathrm{~b}$ & 70.7 & 0.776 & $8.1-8.6$ & 0.50 & $\geq 12.00$ & & $\geq 931$ & & & & \\
\hline \multicolumn{16}{|l|}{ Hole $600 \mathrm{C}$} \\
\hline $0-4.4$ & $1-1,0$ & $1-3,140$ & 4.4 & CN13-15 & 68.2 & 0.843 & $0-1.88$ & 1.88 & 2.52 & & 212 & \multirow{4}{*}{\multicolumn{4}{|c|}{ No change }} \\
\hline $4.4-4.8$ & $1-3,140$ & $1-4,30$ & 0.4 & CN12 & 66.8 & 0.880 & $1.88-3.50$ & $\begin{array}{l}1.62 \\
1.62\end{array}$ & 0.25 & & 22 & & & & \\
\hline $4.8-6.3$ & $1-4,30$ & $1-5,30$ & 1.5 & CN11 & 67.9 & 0.851 & $3.5-3.7$ & 0.2 & 7.50 & & 638 & & & & \\
\hline $6.3-19.0$ & $1-5,30$ & Bottom & 12.7 & - $\mathrm{CN} 10 \mathrm{c}+\mathrm{d}$ & 72.6 & 0.726 & $3.7-4.6$ & 0.9 & $\geq 14.11$ & & $\geq 1024$ & & & & \\
\hline \multicolumn{16}{|l|}{ Hole 601} \\
\hline $0-8.0$ & $1-1,0$ & $1-6,36$ & 8.0 & $\mathrm{CN} 13-15$ & 66.3 & 0.893 & $0-1.88$ & 1.88 & 4.26 & & 380 & \multirow{4}{*}{\multicolumn{4}{|c|}{ No change }} \\
\hline $8.0-8.9$ & $1-6,36$ & $1-6,126$ & 0.9 & CN12 & 66.7 & 0.882 & $1.88-3.50$ & 1.62 & 0.56 & & 49 & & & & \\
\hline $8.9-10.5$ & $1-6,126$ & $2-1,70$ & 1.6 & CN11 & 68.3 & 0.840 & $3.5-3.7$ & 0.2 & 8.00 & & 672 & & & & \\
\hline $10.5-20.4$ & $2-1,70$ & Bottom & 9.9 & $\mathrm{CN} 10 \mathrm{c}+\mathrm{d}$ & 71.7 & 0.750 & $3.7-4.6$ & 0.9 & $\geq 11.00$ & & 2825 & & & & \\
\hline
\end{tabular}



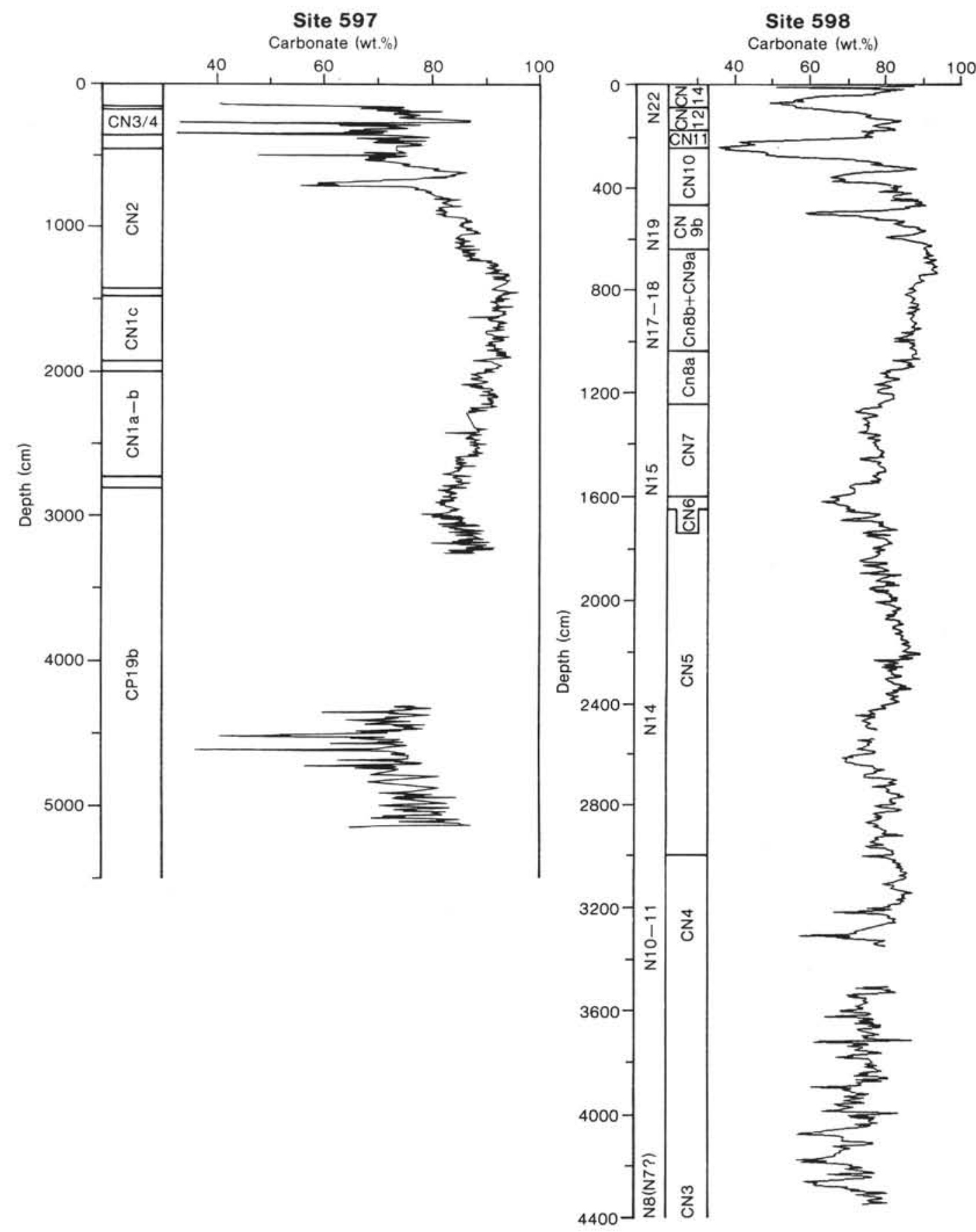

Figure 4. Calcium carbonate contents of Leg 92 sites.

Zone $\mathrm{CN} 9 \mathrm{~b}$ ). This period corresponds to a time, the Messinian, of enhanced ocean circulation and major changes in climate. Some combination of increased abyssal circulation and the features of the local bottom topography may have served to trigger the episodes of (presumably downslope) transport recorded in this reworked section of Site 599 (Rea and Janecek, this volume).

\section{Paleomagnetism of Leg 92 Sediments}

Studies of the paleomagnetism of the sediments recovered from Sites 597, 598, and 599 show unusual in- clinations which increase downcore from $35^{\circ}$ at the seafloor (the present inclination) to $50^{\circ}$ to $60^{\circ}$. What is responsible for this phenomenon is unclear, because all known processes would tend to make magnetic dips more shallow.

\section{Regional Heat Flow}

Heat flow was determined in all drilling areas. The values calculated for Holes 597A, 598A, and 599A are 89,74 , and $101 \mathrm{~mW} / \mathrm{m}^{2}$, respectively, within the low to normal range for crust of equivalent age. Hole 600 was 

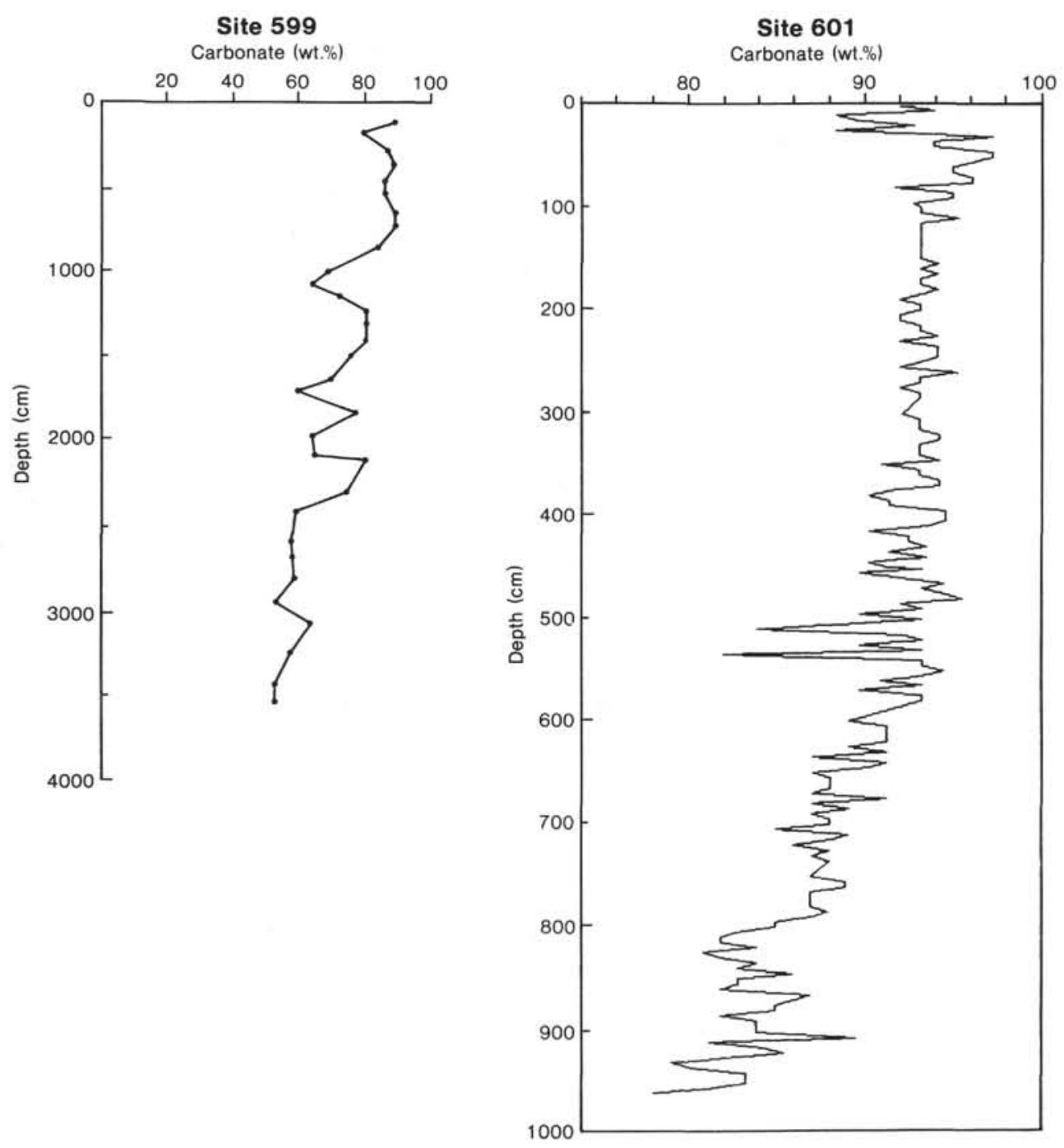

Figure 4. (Continued).

drilled on a precisely located high-heat-flow target, and the value determined for that location is $580 \mathrm{~mW} / \mathrm{m}^{2}$.

\section{HYDROTHERMAL SEDIMENTATION IN THE SOUTHEAST PACIFIC}

\section{Chemistry}

Geochemical and sedimentological studies of the sediments cored on Leg 92 indicate that the noncarbonate fraction is dominated by sediment of hydrothermal origin. As shown in Table 4, the carbonate-free chemistry of much of the sediment column at each site (Lyle, this volume; Marchig and Erzinger, this volume) is nearly identical to that of the iron- and manganese-rich sediments accumulating near the crest of the EPR, which are hydrothermal in origin (Boström and Peterson, 1966; Boström, 1974; Heath and Dymond, 1977; Dymond, 1981; McMurtry et al., 1981; Heath and Dymond, 1981).

$\mathrm{The} \mathrm{Pb}$ isotope composition of the carbonate-free fraction of the Leg 92 sediments, like that of surface hydrothermal sediments from the eastern Pacific spreading cen- ters (Dasch et al., 1971), reflects the mixing of an endmember with the characteristics of ocean-ridge basalt with a more radiogenic end-member (Barrett et al., this volume). Although the bulk carbonate-free fraction was analyzed, the very low concentrations of terrigenous detritus in the Leg 92 sediments (Bloomstine and Rea, this volume) suggest that this more radiogenic end-member is seawater rather than terrigenous debris. The $\mathrm{Pb}$ isotope composition of the sediments from Sites 597 and 598 (the older sites) is significantly more radiogenic than the sediments from Sites 599 to 601 (the sites nearer the ridge axis). Mixing models suggest that 50 to $100 \%$ of the $\mathrm{Pb}$ from the latter is basaltic in origin.

The shale-normalized rare earth element (REE) composition of the bulk sediments is very much like that of seawater and of biogenous carbonate (Ruhlin and Owen, this volume; Barrett et al., this volume), although the absolute abundances of the REE are much greater than those of pure biogenous carbonates and of seawater (Fig. 8). These results also show that the noncarbonate sediments from Leg 92 are much like presently accumulat- 


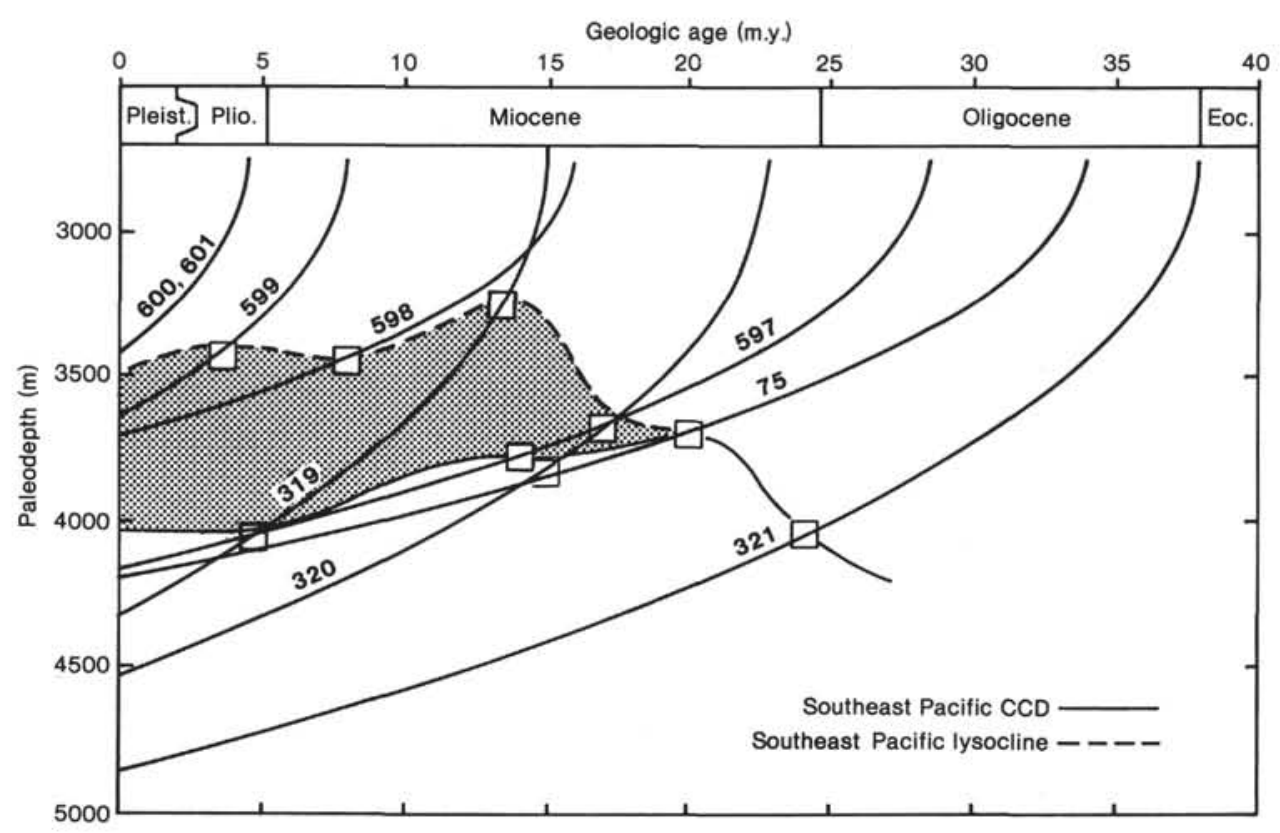

Figure 5. $\mathrm{CaCO}_{3}$ accumulation record plotted on age-depth curves for each site. Squares are 1 m.y. $\times 100$ $\mathrm{m}$ and provide an indication of accuracy. Shaded region emphasizes the depth zone of the lysocline (figure from Rea and Leinen, this volume).

ing hydrothermal phases; previous studies of the REE abundance and composition of the hydrothermal component of surface sediments provide evidence that the REE are scavenged from seawater (Dymond et al., 1973).

\section{Mineralogy}

Smear slide examination of the sediments from the Leg 92 sites indicated that there was very little clay mineral material in the noncarbonate sediment fraction. Like sediments from the East Pacific Rise and the slowly accumulating sediments east of the rise described by Heath and Dymond (1977), Dymond and Eklund (1978), and Lyle (1981), much of the noncarbonate sediment from the younger Leg 92 sites is amorphous and dissolves readily in strong acids and/or mixtures of gentle acid and reducing agents (Leinen and Graybeal, this volume). Most of the noncarbonate fraction from Site 597 was acid insoluble. The acid-insoluble fraction of this material is generally present as red brown to yellow brown semiopaque oxyhydroxides (Kastner, this volume). Unlike the RSOs in sediments of similar appearance described by Leg 34 scientists (Quilty et al., 1976; Bass, 1976), the RSOs in the insoluble residue of the Leg 92 hydrothermal sediments are dominantly goethite (Kastner, this volume). The Leg 92 sediments have little authigenic smectite, unlike the slowly accumulating sediments of similar appearance from the Bauer Deep on the eastern side of the EPR near $13^{\circ} \mathrm{S}$ (Dymond and Eklund, 1978). Biogenic silica has been suggested as a source of silica for the diagenetic change of iron-rich oxides and oxyhydroxides into iron-rich smectites, so the dominance of goethite over smectite may reflect the very low supply of biogenic silica at $19^{\circ} \mathrm{S}$ compared with areas closer to the equatorial high-productivity zone.

\section{Changes in Hydrothermal Sediment Composition in Time and Space}

The Leg 92 transect sites form profiles in time and space of hydrothermal sedimentation west of the ridge crest. They make it possible both to evaluate the evolution of hydrothermal activity at the ridge crest segments that formed Sites 597 to 602 and to study the alteration over time of the hydrothermal sediment once it has been deposited.

Lyle (this volume) and Marchig and Erzinger (this volume) found that the composition of the noncarbonate sediment fraction in the basal sediments from each of the sites was very similar to the composition of presentday sediments close to the EPR. As the sites moved away from their origin at the rise axis, both the amount of hydrothermal material accumulating, as indicated by the $\mathrm{Fe} / \mathrm{Al}$ ratios (which make it possible to eliminate contributions due to terrigenous and basaltic detritus), and the accumulation rates of hydrothermal elements like $\mathrm{Fe}$ and $\mathrm{Mn}$ decreased logarithmically (Lyle et al., this volume; and Fig. 9). This decrease is analogous to the logarithmic decrease in surface sediments west of the EPR with increasing distance from the rise axis in the rate of accumulation of (1) bulk hydrothermal sediment (Dymond, 1981) and (2) individual elements of hydrothermal origin such as Mn (Lyle et al., this volume). Thus, each site can be considered as a diachronous transect from the rise crest west to its present location.

The composition of the noncarbonate sediment fraction at each of the sites changes somewhat with time. The first-order feature of this change is an enrichment in Fe relative to $\mathrm{Mn}$ in this sediments (Fig. 10A). Lyle (this volume) has plotted the $\mathrm{Fe} / \mathrm{Mn}$ ratio of the sedi- 


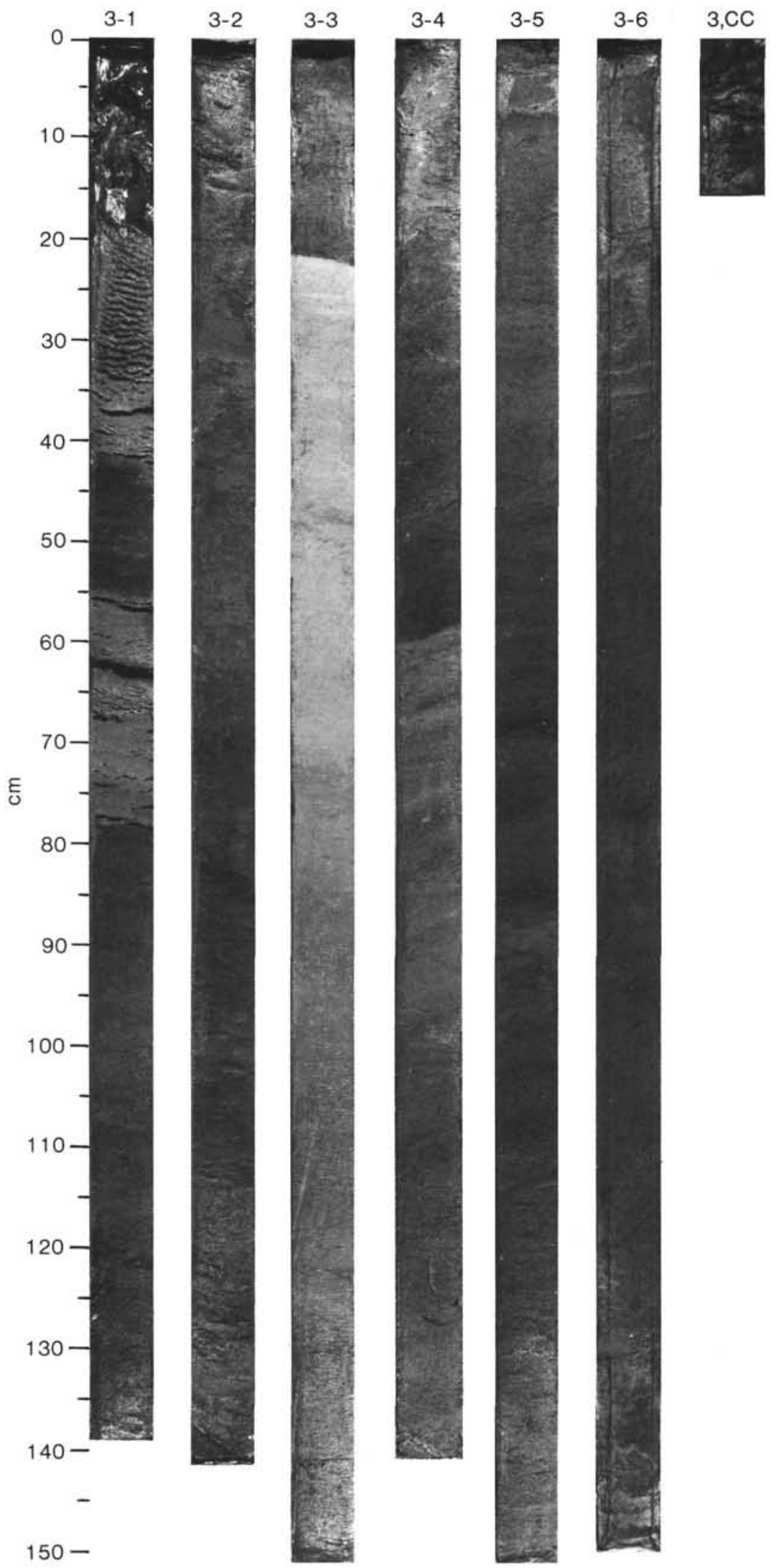

Figure 6. Core 3 from Site 599 . Note the sharp boundaries associated with color changes in the core. 

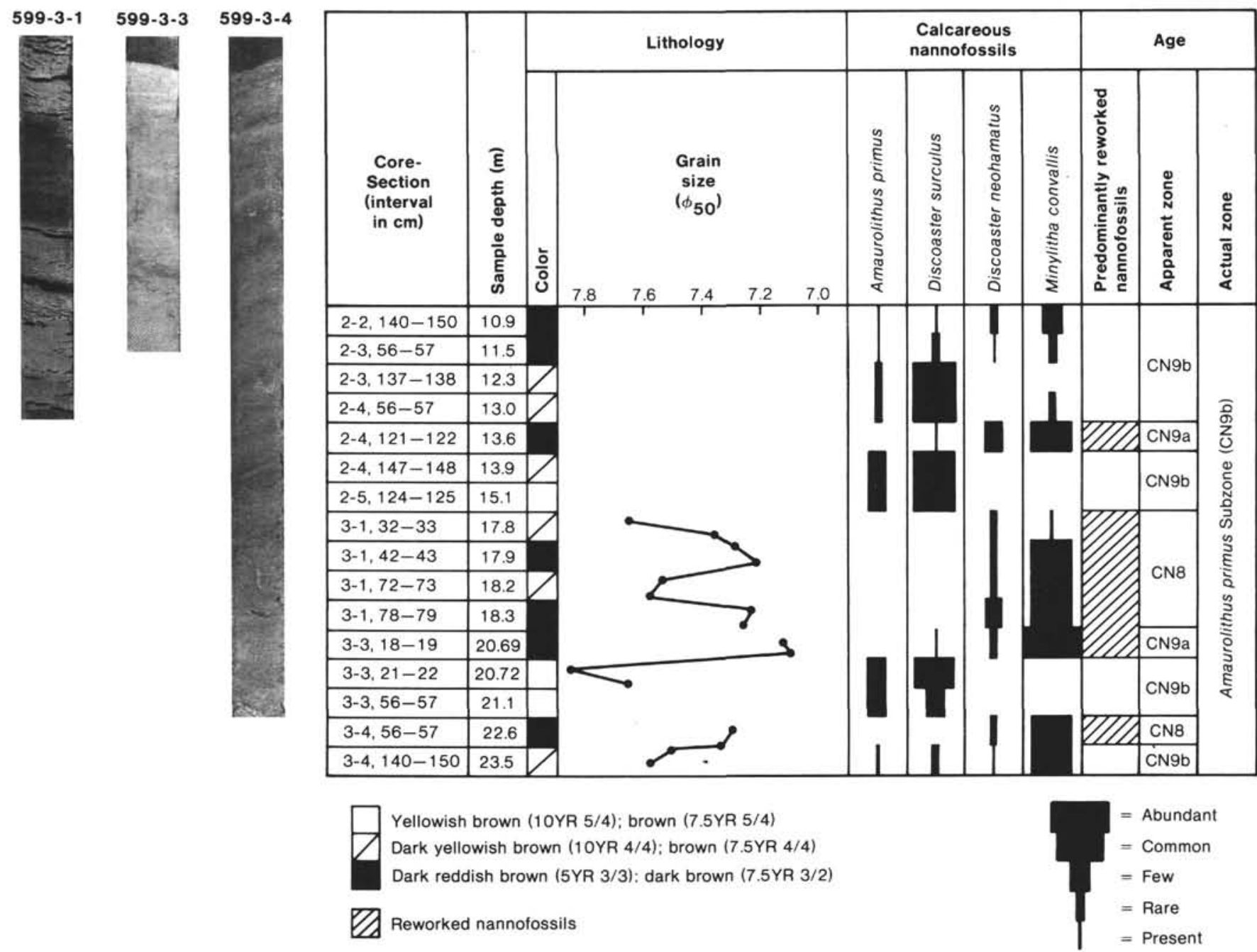

Figure 7. Correlations of sediment color, grain size (Rea and Janecek, this volume), and selected nannofossils present in various samples from Site 599. Grain-size data were plotted to correspond to the same alternating light- or dark-colored band (figure from Knüttel, this volume).

ments from each of the sites versus the site's distance from the rise crest at the time of deposition. $\mathrm{Fe} / \mathrm{Mn}$ ratios typical of presently accumulating hydrothermal sediments $(\approx 3)$ characterize the basal sediments from each site. After the sites reached a distance about $250 \mathrm{~km}$ west of the rise crest at which they formed, the $\mathrm{Fe} / \mathrm{Mn}$ ratio increased to 5 to 7 . As is clear from Figure 10B, this change is a function of the distance of the site from the ridge axis, and it occurs at a different time at each location (Lyle et al., this volume; Marchig and Erzinger, this volume).

There are several possible explanations for the increase in $\mathrm{Fe} / \mathrm{Mn}$ ratio. A small part of the increase may be due to an increase in the amount of terrigenous detritus (which in this region has a very large $\mathrm{Fe} / \mathrm{Mn}$ ratio). However, the small amount of $\mathrm{Al}$ present in the sediments and the very low and constant supply of terrigenous detritus (Bloomstine and Rea, this volume) indicate that the change in ratio is not controlled by an increase in continental debris. It is also unlikely that the change in $\mathrm{Fe} /$ Mn ratio signals a change in the composition of hydrothermal material formed at the rise axis, since the change occurs at a nearly constant distance from the ridge axis but at different times at each of the sites. A change in chemistry due to the dominance of off-axis hydrothermal activity farther than $100 \mathrm{~km}$ from the ridge crest is also unlikely, because experimental studies demonstrate that Fe-rich fluids are produced only at temperatures greater than $300^{\circ} \mathrm{C}$ (Seyfried and Mottl, 1982). These lines of evidence suggest that the change in composition of the hydrothermal component accumulating at these distal sites is caused by the separation of $\mathrm{Fe}$ from $\mathrm{Mn}$ during mid- to deep-water transport (Lyle, this volume; Marchig and Erzinger, this volume), although the sense of the change is opposite that expected from the relative solubilities of iron and manganese hydroxide and oxide colloids. It may be that manganese oxide colloids are more readily scavenged onto particulates falling through the water column than are iron oxide colloids (Lyle, this volume; Weiss, 1977).

Once deposited, the hydrothermal component undergoes some diagenetic transformation. In the Leg 92 sediments, the primary reaction is a recrystallization of the iron-rich oxide and oxyhydroxide to goethite (Kastner, 
Table 4A. Chemical composition (wt.\%) of hydrothermal sediments from Leg 92 sites and East Pacific Rise.

\begin{tabular}{lccc}
\hline & $\begin{array}{c}\text { East Pacific Rise } \\
\text { (Heath and Dymond, 1977) }\end{array}$ & $\begin{array}{c}\text { Sites 597, 598, 599 } \\
\text { (Lyle, this volume) }\end{array}$ & $\begin{array}{c}\text { All Leg 92 sites } \\
\text { (Marchig and Erzinger, } \\
\text { this volume) }\end{array}$ \\
\hline $\mathrm{Al}$ & 0.26 & 0.00 & 0.98 \\
$\mathrm{Si}$ & 4.12 & 2.69 & 4.62 \\
$\mathrm{Mn}$ & 12.37 & 11.25 & 8.51 \\
$\mathrm{Fe}$ & 41.22 & 28.66 & 36.81 \\
$\mathrm{Ni}$ & 0.0638 & $\mathrm{NA}$ & 0.067 \\
$\mathrm{Cu}$ & 0.1892 & $\mathrm{NA}$ & 0.140 \\
$\mathrm{Zn}$ & 0.0411 & $\mathrm{NA}$ & $\mathrm{NA}$ \\
$\mathrm{Ba}$ & 0.33 & 0.12 & 0.259 \\
\hline
\end{tabular}

Table 4B. Element ratios in hydrothermal sediments from Leg 92 sites and East Pacific Rise.

\begin{tabular}{lcccc}
\hline & $\begin{array}{c}\text { Site 598 } \\
\text { (Dyst Pacific Rise } \\
\text { (Ruhlin and Owen, 1981) } \\
\text { this volume) }\end{array}$ & $\begin{array}{c}\text { Sites 597, 598, 599 } \\
\text { (Lyle, this volume) }\end{array}$ & $\begin{array}{c}\text { All Leg 92 sites } \\
\text { (Marchig and Erzinger, } \\
\text { this volume) }\end{array}$ \\
\hline $\mathrm{Al} / \mathrm{Fe}$ & 0.0060 & & 0.0000 & 0.0266 \\
$\mathrm{Si} / \mathrm{Fe}$ & 0.1300 & & 0.0939 & 0.1255 \\
$\mathrm{Mn} / \mathrm{Fe}$ & 0.2900 & 0.2799 & 0.3924 & 0.2312 \\
$\mathrm{Ni} / \mathrm{Fe}$ & 0.0009 & 0.0221 & & 0.0018 \\
$\mathrm{Cu} / \mathrm{Fe}$ & 0.0042 & 0.0017 & & \\
$\mathrm{Zn} / \mathrm{Fe}$ & 0.0019 & 0.0049 & 0.0042 & 0.0070 \\
$\mathrm{Ba} / \mathrm{Fe}$ & 0.0050 & & & \\
\hline
\end{tabular}

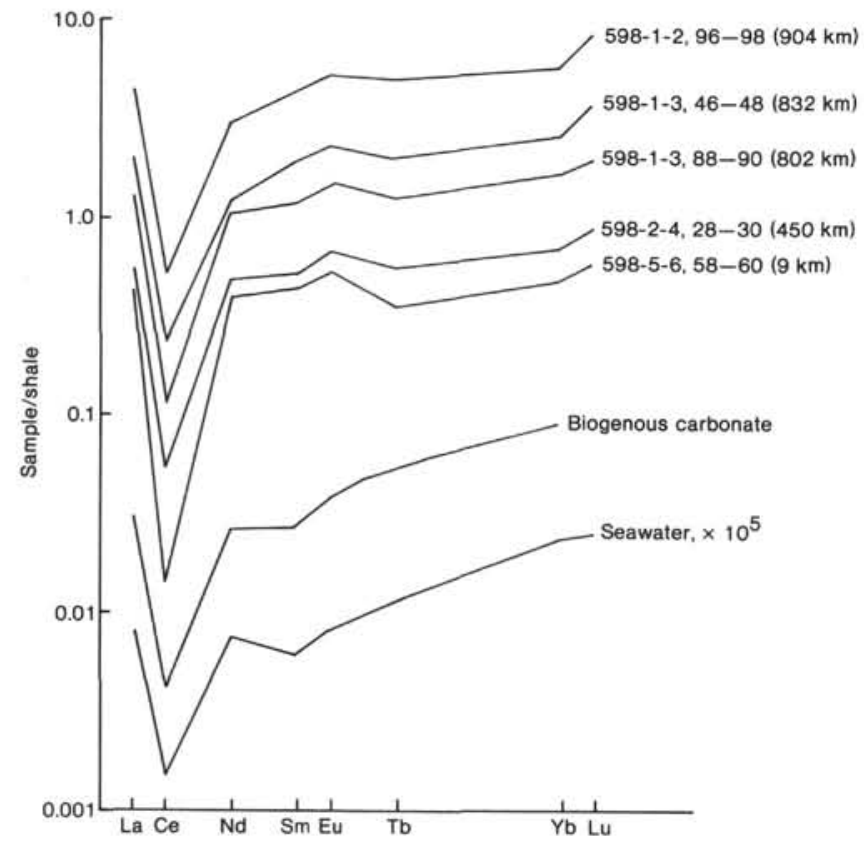

Figure 8. Shale-normalized REE patterns for representative Site 598 sediment samples, biogenous carbonate (Elderfield and Greaves, $1981)$, and seawater $\left(\times 10^{5}\right)$. Values in parentheses indicate distance of site from the rise crest at time of sediment deposition (figure from Ruhlin and Owen, this volume).

this volume). The variations in crystallinity of the goethite with depth and with lithology suggest that age and the length of time the oxyhydroxide is exposed to seawater control the degree of recrystallization rather than depth

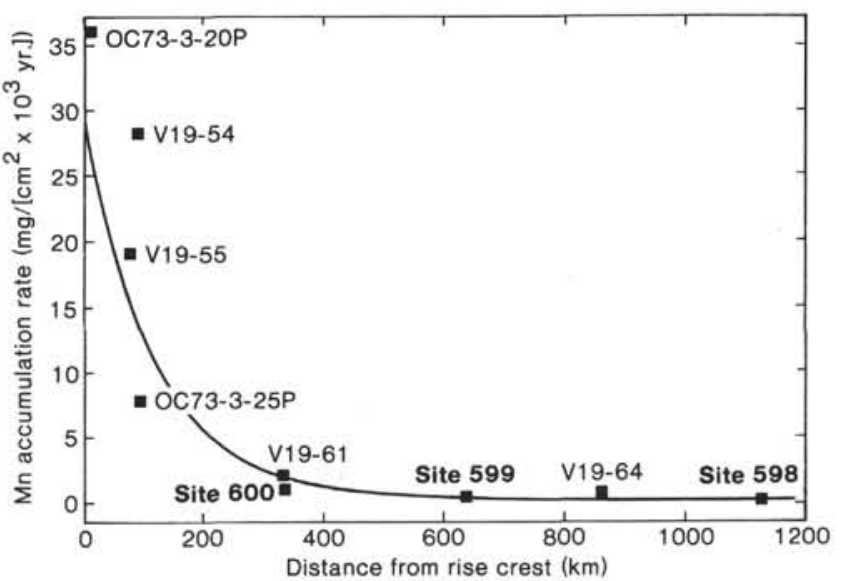

Figure 9. Manganese accumulation rate in surface sediments at the East Pacific Rise between $14^{\circ}$ and $20^{\circ} \mathrm{S}$ as a function of distance from the rise crest. The line is the best fit to the data of Lyle et al. (this volume).

of burial or the lithology of the associated sediment (Kastner, this volume).

\section{Changes in Hydrothermal Accumulation with Time}

The overall similarity in composition of hydrothermal phases deposited west of the EPR during the last 28.6 m.y. suggests that changes in the accumulation of the hydrothermal sediment, or in the accumulation of elements which are dominantly of hydrothermal origin, must be related to changes in the rate of deposition, not changes in the chemistry of hydrothermal vents. Because the accumulation rate of hydrothermal phases is partial- 
A

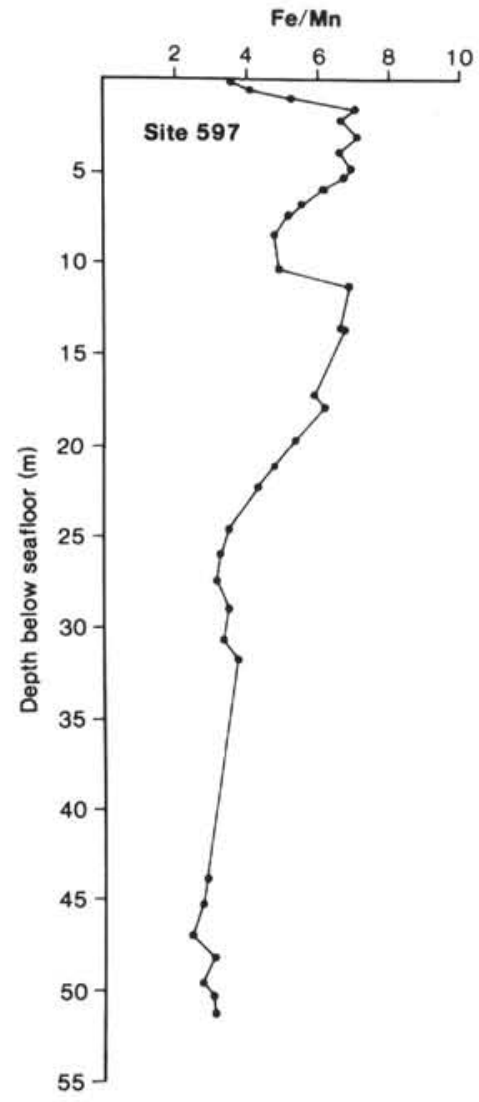

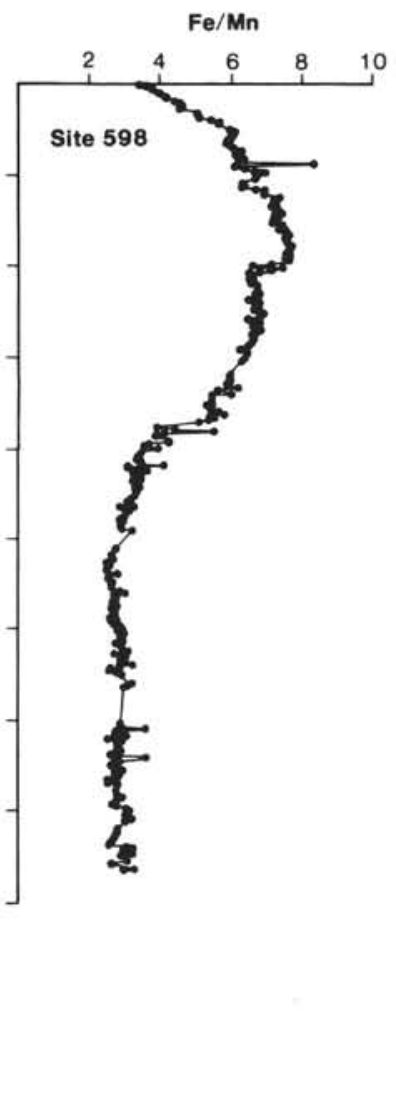

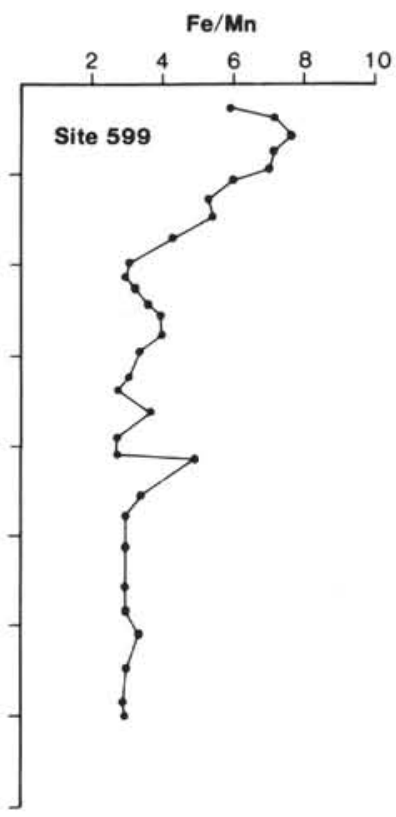

B

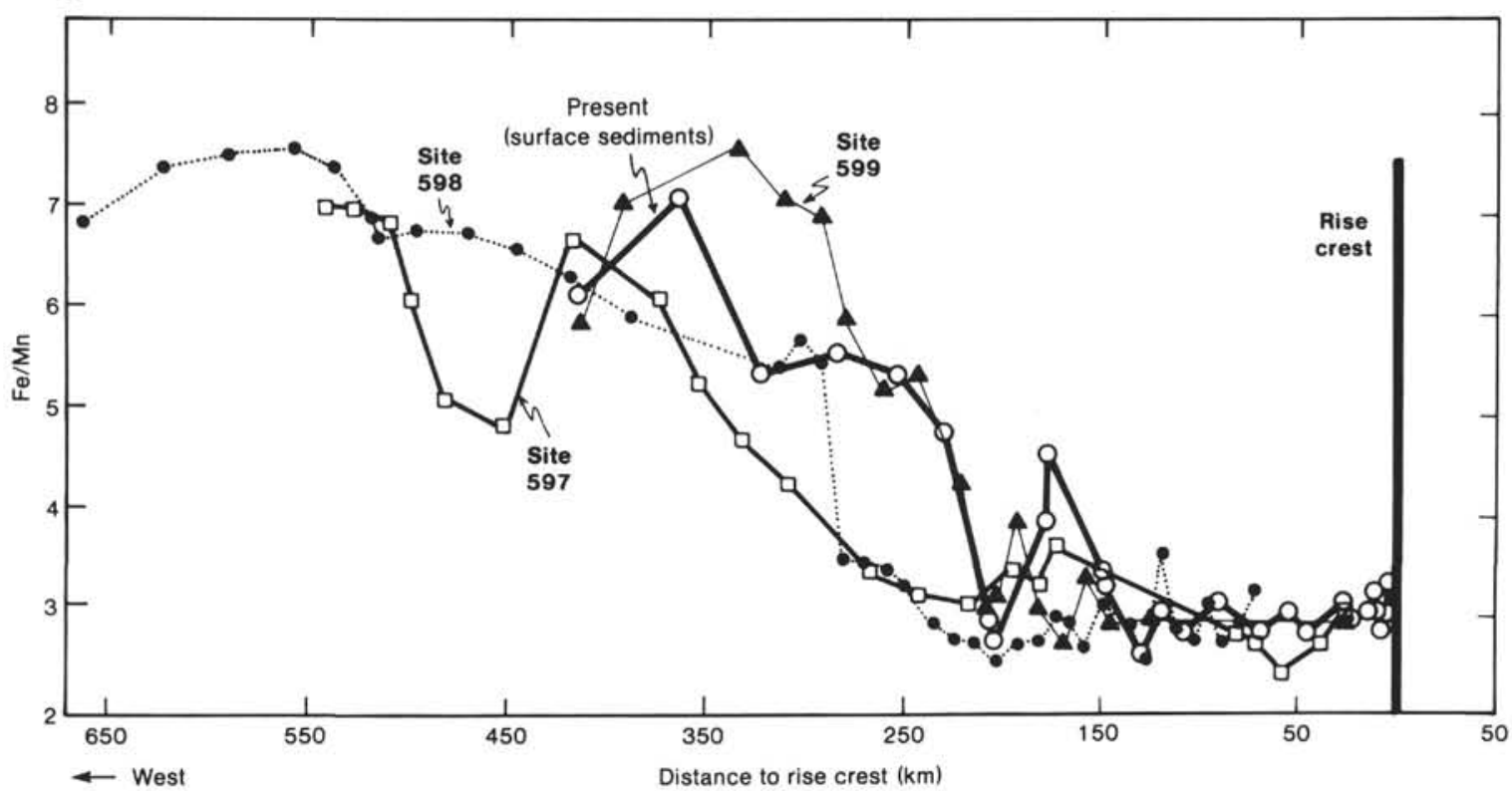

Figure 10. A. Fe/Mn profiles for Sites 597,598 , and 599 . Low Fe/Mn ratio $(\approx 3)$ in basal sediments is similar to that observed by Dymond (1981). B. Comparison of $\mathrm{Fe} / \mathrm{Mn}$ ratios in Leg 92 cores to $\mathrm{Fe} / \mathrm{Mn}$ in present-day sediments. The transition from low to high $\mathrm{Fe} / \mathrm{Mn}$ occurs at approximately the same distance from the rise crest in ancient and present-day sediments (figure from Lyle, this volume).

ly a function of distance from the ridge crest, changes in the accumulation of hydrothermal material at each site with time must be compared with accumulation rates at similar distances from the ridge axis today (Lyle et al., this volume). Such a comparison suggests that there are anomalous increases in the accumulation rate of hydro- thermal phases at Site 597 about 23 to $27 \mathrm{Ma}$ and 17.0 to $18.5 \mathrm{Ma}$ (Fig. 11A), and at Site 598 about 12 to 16 Ma and 8 to $11 \mathrm{Ma}$ (Fig. 11B).

Site 597 lies on crust formed at the Mendoza Rise (Mammerickx et al., 1980; and Fig. 2). After the site's location moved west for about $10 \mathrm{~m}$.y. (roughly $550 \mathrm{~km}$ ), 

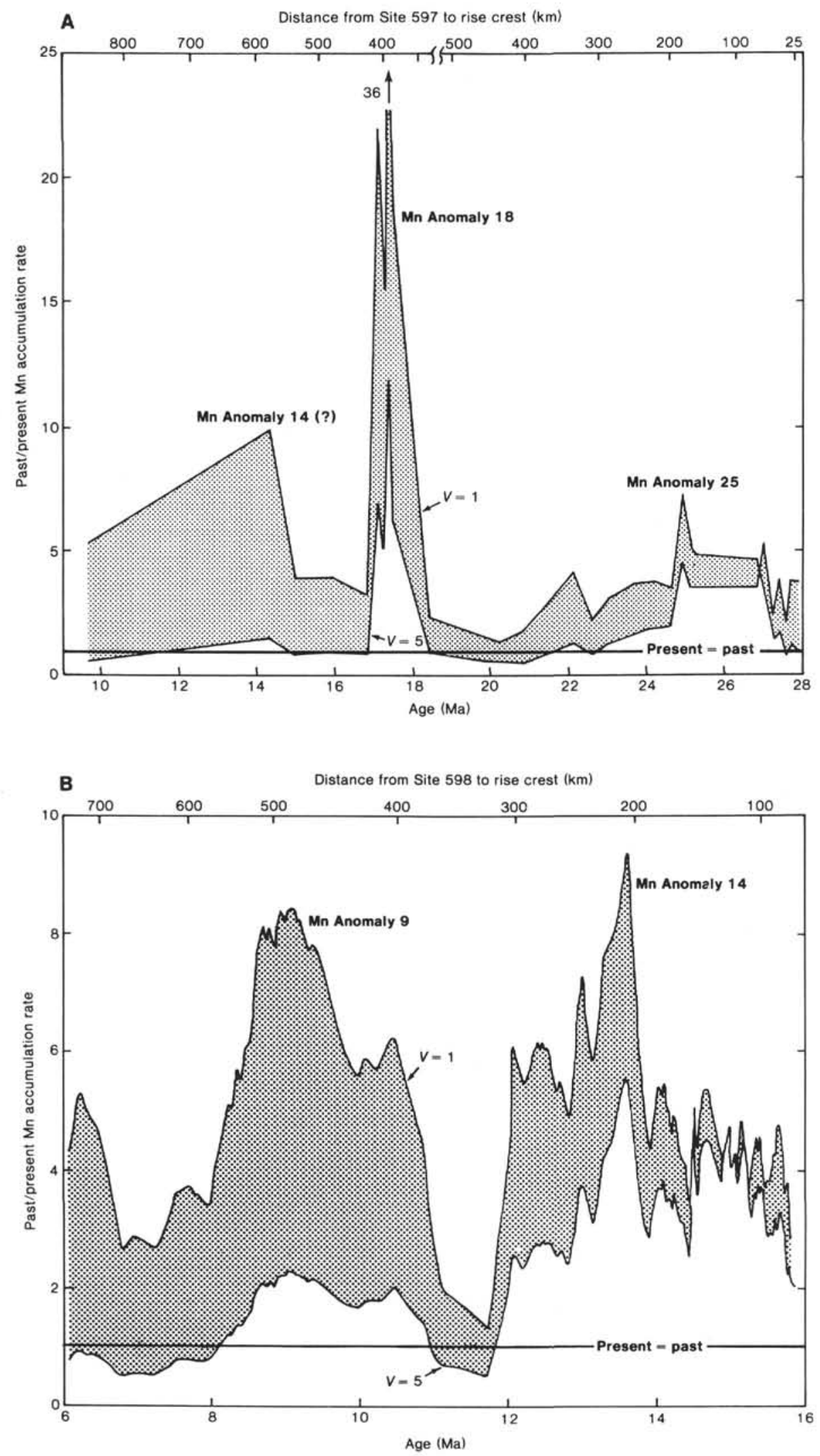

Figure 11. Anomalous manganese accumulation rates versus age at (A) Hole 597 and (B) Hole 598 (from Lyle et al., this volume). Shaded area is the ratio of past to present manganese flux calculated by assuming velocities of transporting deep-sea currents $(V)$ of between 1 and $5 \mathrm{~cm} / \mathrm{s}$. Line across the bottom of the figures is where this ratio is equal to 1 (the past $\mathrm{Mn}$ flux is the same as the present flux). Large manganese accumulation anomalies record hydrothermal events at 27 to $23 \mathrm{Ma}$ and 18.5 to $17 \mathrm{Ma}$ in Hole 597 , and at about 16 to $12 \mathrm{Ma}$ and 10.5 to $8 \mathrm{Ma}$ in Hole 598 . Note different scales in parts A and B. 
the spreading center jumped west, and the new EPR became established between its previous position and the paleoposition of Site 597. Thus, Site 597 was once again much closer to a spreading center. Lyle et al. (this volume) report that the timing of an increase in hydrothermal Mn accumulation and an accompanying change in the $\mathrm{Mn} / \mathrm{Al}$ ratio of the noncarbonate sediments at Site 597 from 17.0 to 18.5 Ma suggest that these phenomena may be a result of the ridge jump which occurred at approximately the same time (18.4 to $20 \mathrm{Ma}$, Mammerickx et al., 1980). The magnitude of the hydrothermal accumulation after the ridge jump is several times larger than that predicted only by moving the rise closer to the place of accumulation (Lyle et al., this volume). Thus, the increase in accumulation rates may reflect enhanced hydrothermal activity associated with the rearrangement of spreading axes (Fig. 12).

The hydrothermal $\mathrm{Mn}$ and $\mathrm{Fe}$ accumulation records at Sites 598 and 599 are quite variable (Lyle et al., this volume; Ruhlin and Owen, this volume). Two time intervals at Site 598 have $\mathrm{Mn}$ accumulation rate anomalies that are two to nine times greater than the present $\mathrm{Mn}$ accumulation rate for equivalent distances from the rise crest (Fig. 11B). These time intervals bracket the Catinaster coalitus nannofossil Zone (CN6), which is changed by over a million years in duration as a result of biostratigraphic changes proposed by Berggren et al. (1985).
The stratigraphic changes would decrease the accumulation rates.

\section{INTERSTITIAL WATER STUDIES AND OTHER GEOCHEMICAL EVIDENCE OF OFF-AXIS CONVECTIVE FLUID FLOW}

Heat-flow surveys and pore water profiles of major ion constituents (Bender, 1983; Maris and Bender, 1982) and of nutrients (Bender et al., in press) provide evidence of ridge flank pore water advection and chemical exchange in off-axis hydrothermal areas such as the Galapagos Mounds and Mariana Mounds. These studies suggest that the low regional conductive heat flow which is typical of such areas is the result of cooling by fluid advection. One of the principal goals of Leg 92 was to evaluate the importance of ridge flank hydrothermal activity and pore water advection and their relationship to the regional heat flow on the flank of the EPR; the heat flow is below that expected from theoretical conductive cooling (Anderson et al., 1977, 1979).

The site surveys for Sites 597 and 599, which included both heat-flow and pore water studies, found no evidence of the high heat flow characteristic of local sites of vertical advection and no evidence of the pore water gradients characteristic of advection (Bender et al., in press; Leinen and Graybeal, this volume). The Site 598 area was not surveyed. The site surveys did find areas of

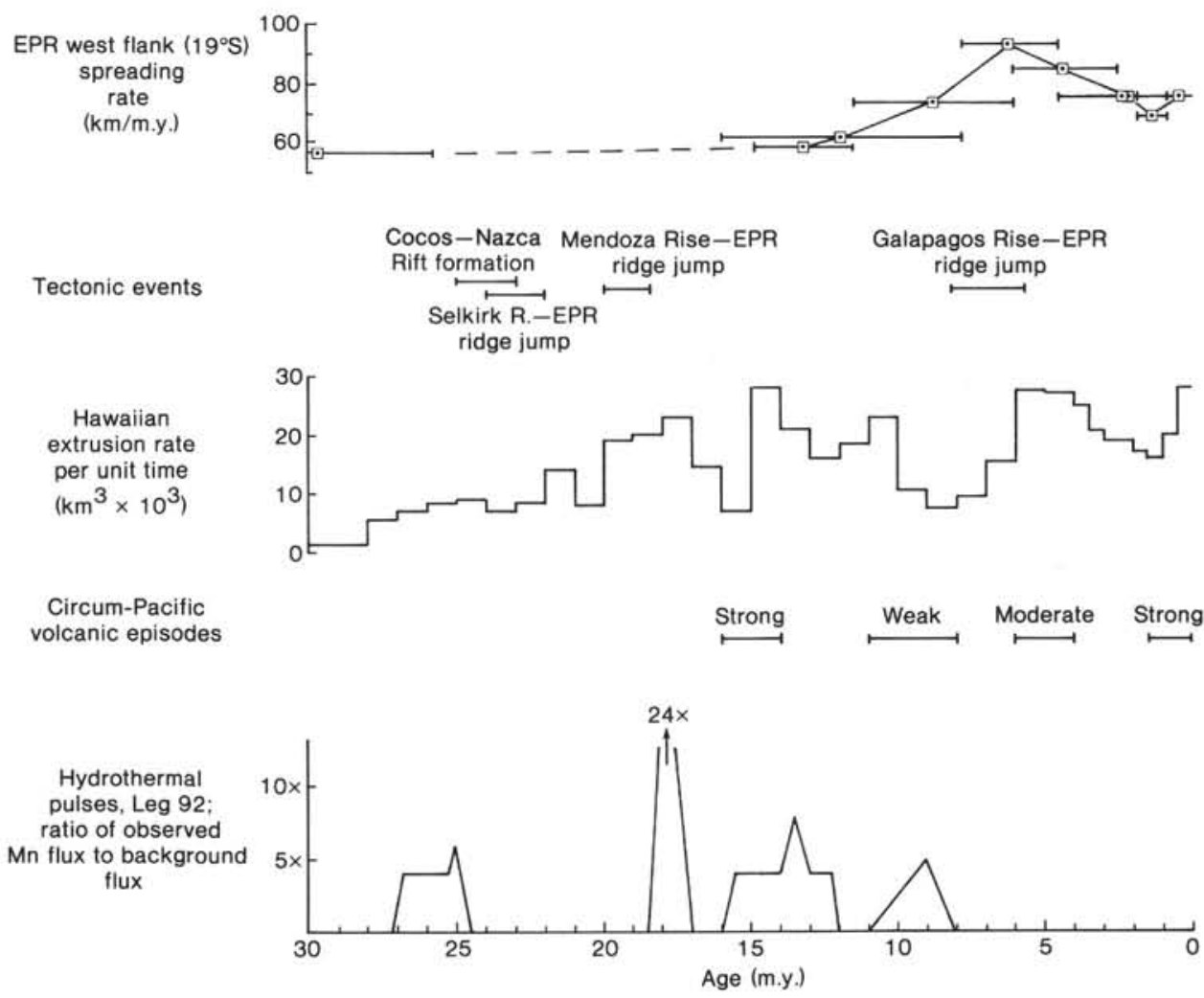

Figure 12. Temporal patterns of seafloor spreading rate, spreading axis jumps, mid-plate and circum-Pacific volcanic activity, and flux of hydrothermal material to the sediments. Spreading rates from Rea (this volume and 1978b); timing of axis jumps from Hey (1977), Mammerickx et al. (1980), and Rea (1978a); historical extrusion rate along the Hawaiian Ridge from Rea and Scheidegger (1979); circumPacific volcanic episodes from Kennett et al. (1977); hydrothermal accumulation pattern from Lyle et al. (this volume; and Fig. 11). 
high, intermediate, and low heat flow in the region surveyed for Sites 600,601 , and 602 , respectively. The heat flow in the region of Site 600 was more than double the theoretical heat flow for crust of 4.5 m.y. age, but the pore water profiles were somewhat ambiguous (Bender et al., in press). We were therefore particularly interested in whether the sediments and pore waters from Site 600 showed evidence of active vertical fluid flow. Interstitial water studies by Gieskes and Boulègue (this volume) showed only very small changes in major ionic constituents, however. There were small downcore increases in $\mathrm{Ca}^{2+}\left(\leq 1 \mathrm{mM}\right.$ ), and slight decreases in $\mathrm{Mg}^{2+}$ (generally $<1 \mathrm{mM})$. The nutrient profiles, however, showed no evidence that these changes were due to advection. It is more likely that they are the result of reactions occurring in the sediment column, such as carbonate dissolution and recrystallization and/or the alteration of small amounts of volcanic material (Gieskes and Boulègue, this volume).

The Pliocene basal sediments of Hole $600 \mathrm{C}$ do show evidence of advective fluid flow and associated alteration in the past, however. There is extensive evidence of $\mathrm{CaCO}_{3}$ dissolution and recrystallization in the Pliocene sediments in the hole (Knüttel, this volume; Romine, this volume; Kastner et al., this volume), even though the drill site is and has been above the lysocline during its entire history (Rea and Leinen, this volume). Strontium, magnesium, oxygen isotope, and carbon isotope profiles of the carbonate fraction of these sediments suggest that this carbonate diagenesis is the result of advective fluid flow through the sediments during the first 1 to $1.5 \mathrm{~m} . \mathrm{y}$. of sedimentation (Kastner et al., this volume). During this period the site would have been within about $115 \mathrm{~km}$ of the ridge crest.

\section{PETROLOGY AND GEOPHYSICAL PROPERTIES OF BASEMENT ROCKS FROM THE FAST-SPREADING MENDOZA RISE}

\section{Petrology}

Most of the basalts recovered on Leg 92 were tholeiites, consisting of plagioclase-clinopyroxene basalts with titanomagnetite and sometimes olivine (Goldfarb, this volume). Rocks from Hole 601B are ferrobasalts, and those from Hole 602B are alkali basalts (Pearce et al., this volume).

The re-entry hole, 597C, which penetrated $91 \mathrm{~m}$ of basalt and from which $48.5 \mathrm{~m}$ of rock were recovered, is the most successful drill hole to date in crust formed at fast spreading rates. Both petrography and geochemistry indicate that the basalts recovered from Hole 597C can be subdivided into three units. Each unit is made up almost entirely of massive flows; one possible pillow fragment was recovered at the top of the basalt column. The three units are differentiated by the absence of olivine in the middle unit (Goldfarb, this volume) and by minor and trace metal chemistry (Pearce et al., this volume; Erzinger, this volume; and Fig. 13). Pearce et al. (this volume) consider Unit III (121.3 to $143.5 \mathrm{~m}$ below seafloor), which is basalt with olivine and 8 to $10 \mathrm{wt} . \%$ $\mathrm{MgO}$, to be unusually basic; Unit II (100.5 to $121.3 \mathrm{~m}$ ), basalt with no olivine and 6 to $7.5 \mathrm{wt} . \% \mathrm{MgO}$, to be

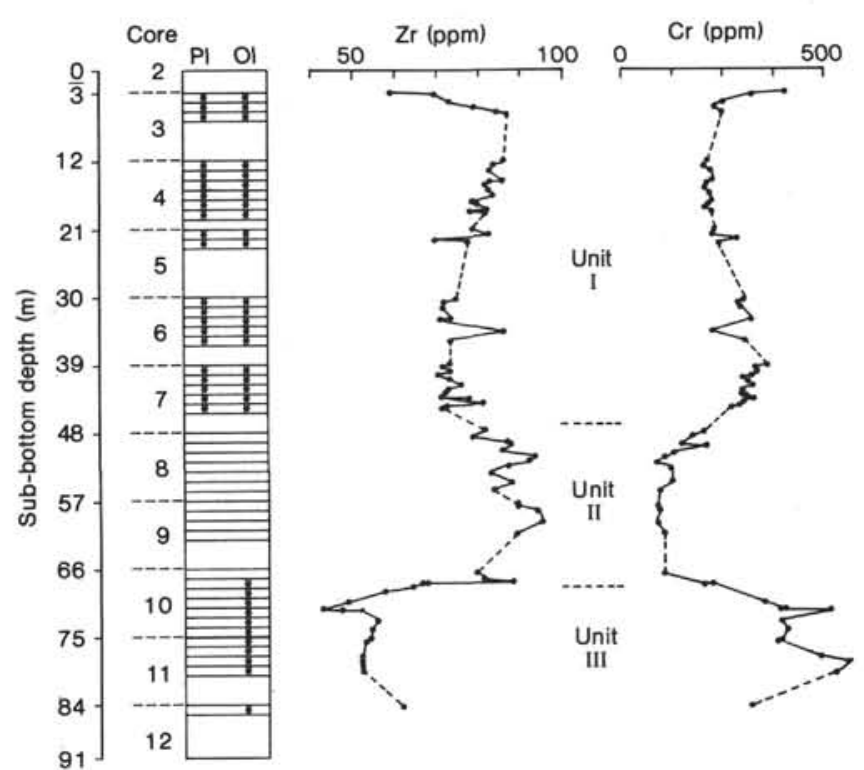

Figure 13. Geochemical stratigraphy of Hole $597 \mathrm{C}$ as exemplified by the elements $\mathrm{Zr}$ and $\mathrm{Cr}$. Core sections with asterisks contain plagioclase glomerocrysts $(\mathrm{Pl})$ and modal olivine $(\mathrm{Ol})$. From Pearce et al. (this volume).

most evolved; and Unit I ( 52.5 to $100.5 \mathrm{~m})$ to be intermediate in composition between the other two.

The alteration mineral assemblages in the basaltic section at Site 597 provided a great deal of information about the nature, sequence, and timing of the seawater alteration of the crust. The basalts have been subjected to three stages of alteration. The earliest, deuteric, alteration stage resulted in the formation of blue smectites (Fig. 14A); a second nonoxidative, hydrothermal alteration stage resulted in the formation of chlorite, talc, green smectites, sulfides, and native copper (Fig. 14B); and a final oxidizing phase (presumably low-temperature seawater alteration) resulted in the formation of calcite, zeolites, brown smectites, and iron oxyhydroxides (Fig. 14C; Pearce et al., this volume; Erzinger, this volume; Peterson et al., this volume).

The magnitude of the flux of hydrothermal materials to the ocean depends, in part, on how long the hydrothermal systems are active. To quantify the duration of the hydrothermal activity at Site 597, Peterson et al. (this volume) determined $\mathrm{K} / \mathrm{Ar}$ ages for protoceladonite and celadonite recovered from veins in basalts from Holes 597B and 597C. At Hole 597B, protoceladonite has an age of $13.1 \pm 0.3 \mathrm{~m} . \mathrm{y}$.; at Hole 597C the ages from two samples are $19.9 \pm 0.4$ and $19.3 \pm 1.6$ m.y. Seafloor age at this site is well constrained at $28.6 \mathrm{~m}$.y., so the vein fillings are 9 to $15 \mathrm{~m}$.y. younger. These values suggest that seawater continues to circulate through the rocks to generate alteration for 9 to $15 \mathrm{~m}$.y. after their formation. This length of time corresponds to distances of 500 to $800 \mathrm{~km}$ from the ridge axis at typical EPR spreading rates.

\section{Geophysical Studies of Site 597}

Several geophysical studies were performed on samples from or in the boreholes of Site 597. The physical properties of basalts recovered from Hole 597C have been 
A

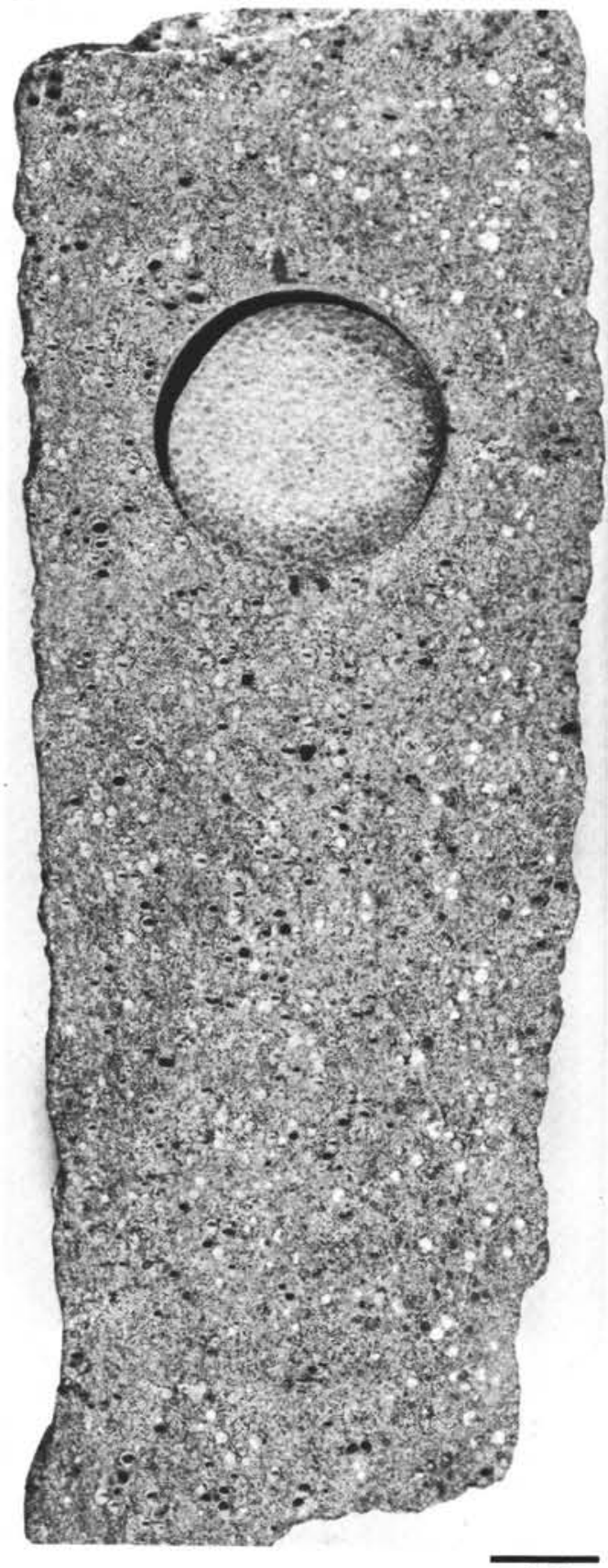

B

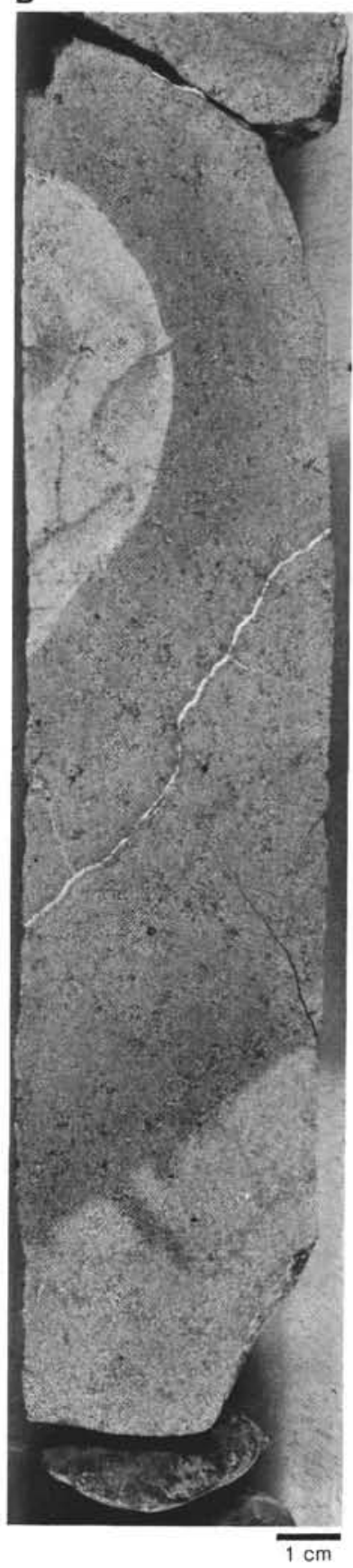

C

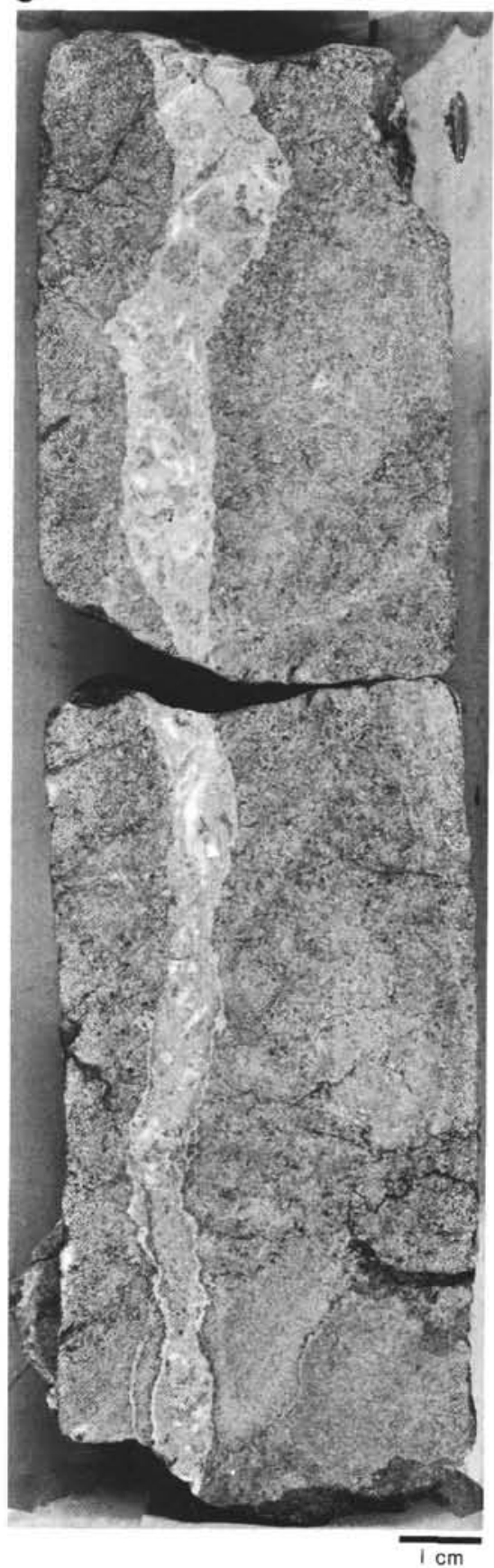

Figure 14. Altered rocks from Hole 597C. A. Vesicles in basalt filled with the blue smectite characteristic of Stage 1 alteration (Hole 597C, Core 3, Section 1, Piece 7). B. Basalt with the alteration rim characteristic of Stage 2 alteration (Hole 597C, Core 4, Section 1). C. Basalt with large vein filled with iron oxide and calcite; Stage 3 alteration (Hole 597C, Core 6, Section 1).

determined by Newmark and Moos (this volume). Bulk densities range from 2.69 to $3.05 \mathrm{~g} / \mathrm{cm}^{3}$. Sonic velocities, measured at in situ pressures, are 5.7 to $6.81 \mathrm{~km} / \mathrm{s}$ for compressional waves and 1.66 to $3.84 \mathrm{~km} / \mathrm{s}$ for shear waves.

Paleomagnetic analyses of basalt samples completed by Nishitani (this volume) show that the seafloor at Site 597 is reversely magnetized; all samples have a positive inclination except for two (597C-7-4, 137-140 cm; 597C$7-5,70-73 \mathrm{~cm}$ ), which showed negative inclinations or normal polarity (Fig. 15). This information and the sea- floor spreading anomalies (Rea, this volume) indicate that Site 597 is located on reversely polarized crust of Chron 8R, between Anomalies 8 and 9, and so is 28.27 to 28.73 m.y. in age (Harland et al., 1982). This age is slightly greater than the age of the basal nannofossil zone, CP19B, which spans 27.8 to 24.8 m.y. (Haq, 1984). We note, however, that the Haq (1984) zonations are referred to the Ness et al. (1980) magnetic reversal time scale, which places Chron $8 \mathrm{R}$ at 27.21 to $27.61 \mathrm{Ma}$.

The measured inclinations are unusually high for the latitude of Site 597 (about $18.8^{\circ} \mathrm{S}$ ). After alternating- 

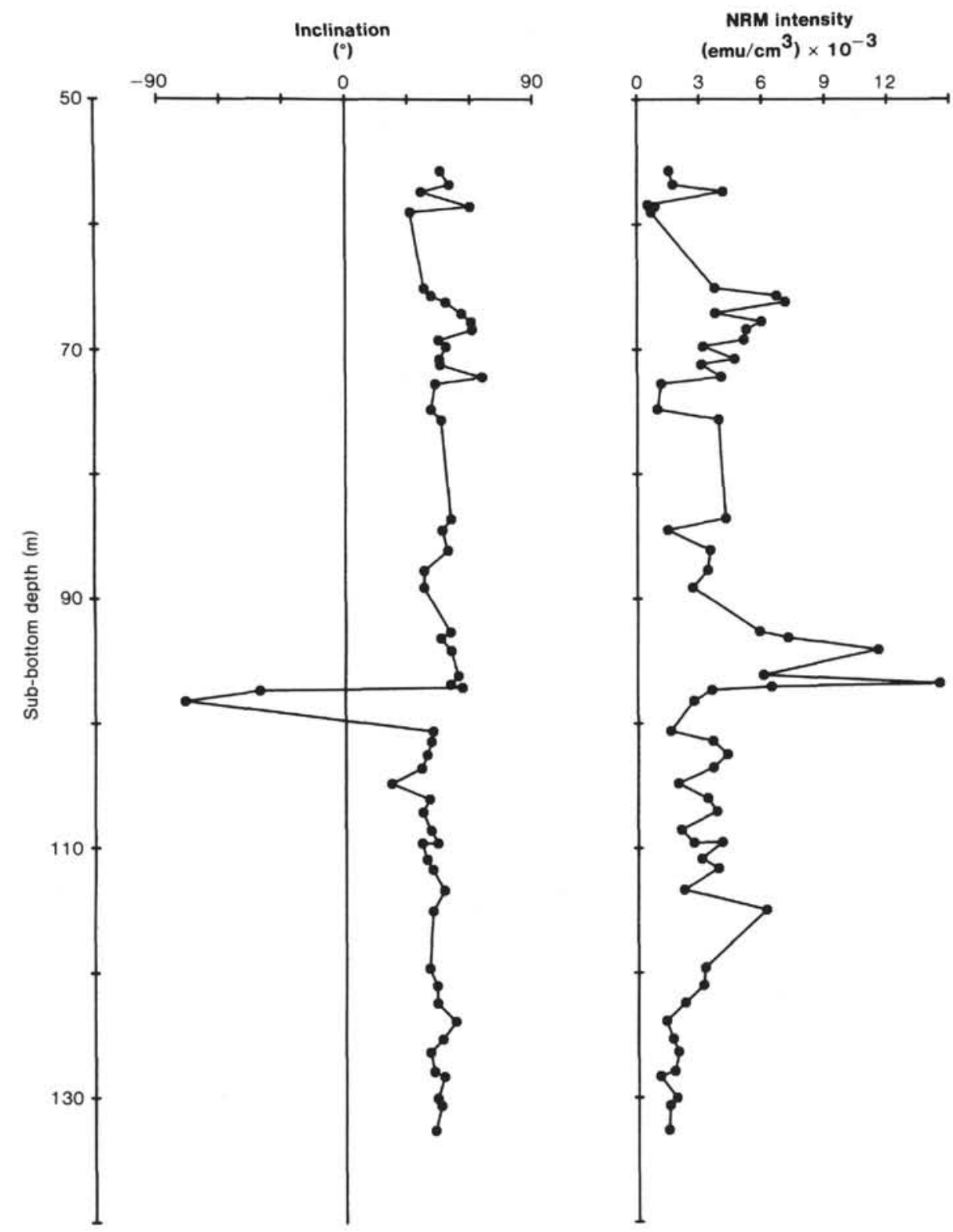

Figure 15. Magnetic inclination of samples from Hole 597C after alternating-field demagnetization.

field demagnetization at $900 \mathrm{Oe}$, they average $45^{\circ}$ (Nishitani, this volume). The magnetic inclination at $18.8^{\circ} \mathrm{S}$ should be about $34^{\circ}$. Unusually high inclinations also characterize the basalts from DSDP Sites 319 and 320 (Ade-Hall and Johnson, 1976), which are on crust generated at the fossil Galapagos Rise. There is as yet no satisfactory explanation for these high inclinations, since tectonic reconstructions appear to rule out any significant northward drift of the seafloor and all faulting schemes act to reduce inclinations.

Logging operations at Hole $597 \mathrm{C}$ included a caliper $\log$ and a borehole televiewer run. The results of the caliper log are presented in the Site 597 chapter (this volume) and indicate that hole diameter increases in rubbly zones of low basalt recovery. The televiewer provides a continuous $360^{\circ}$ scan of the inside of the borehole. Initially round holes respond to stresses in the lithosphere and deform as "breakouts" occur, resulting in an ellipti- cal outline. The ellipse is elongated in the direction of least principal stress. At Hole 597C, breakouts are oriented $\mathrm{N} 20^{\circ} \mathrm{E} \pm 25^{\circ}$, so maximum horizontal compression is oriented $\mathrm{N} 110^{\circ} \mathrm{E} \pm 25^{\circ}$, parallel to the direction of both absolute and relative plate motion at Site 597 (Newmark et al., 1984 and this volume).

A packer experiment in Hole 597C, which was made to determine the permeability and formation pressure of the crust, was partially successful. Results indicated that the lower portions of Hole 597C are characterized by high permeability and are relatively underpressured, so that seawater tends to flow into the formation.

\section{CONCLUDING REMARKS}

The samples recovered by Leg 92 have provided the information necessary to answer several important questions about the nature and history of controls on basalt-seawater (hydrogeology) interactions. The sediments 
drilled on the leg confirm that over the last 28.6 m.y. a hydrothermal component nearly identical in composition to that forming today at the East Pacific Rise has formed at southeast Pacific spreading centers and has been transported great distances by mid- and bottomwater circulation. The sediments deposited as a result of this activity provide a temporal record of the Neogene history of hydrothermal deposition in the southeast $\mathrm{Pa}$ cific. They suggest that there has been at least one episode of greatly enhanced hydrothermal activity at south Pacific spreading centers during the last $28.6 \mathrm{~m}$.y. which occurred about $18 \mathrm{Ma}$. This interval is at the same time that the spreading axis jumped west from the Mendoza Rise to the East Pacific Rise. The Leg 92 sediments suggest that there was an increase of at least one order of magnitude in the amount of hydrothermal sediment being transported away from the area of the ridge axis at this time. The sediments from the Leg 92 sites record other changes in the accumulation of hydrothermal phases and elements dominantly of hydrothermal origin, but these changes are of much smaller magnitude and cannot be unequivocally attributed to changes in ridge crest hydrothermal activity (Fig. 12).

Studies of present-day hydrothermal sediments have suggested that one of the most important controls on their distribution and accumulation rate is the spreading rate of the ridge at which they are generated. The rate of seafloor spreading over the time interval represented by the Leg 92 cores has changed by as much as $50 \%$ (Fig. 12). Nonetheless, there is no apparent relationship between the spreading rate of the ridge crest segment that generated the Leg 92 transect sites and the accumulation rate of the hydrothermal sediment along that transect. It may be that much greater differences in spreading rate are necessary to generate hydrothermal accumulation rate anomalies large enough to be resolved in distal hydrothermal sediments.

Basement rocks drilled from this region of fast-spreading ridges have been altered in three stages, each of which has a different chemical and mineralogical signature. Radiometric age dating suggests that the alteration process goes on for about $10 \mathrm{~m}$.y. after the basalt is formed. This time interval corresponds to hundreds of kilometers of distance from the ridge axis and suggests that off-axis hydrothermal alteration of basalt is an important process in the south Pacific. The core recovered from Hole $600 \mathrm{C}$ shows evidence of sediment alteration and diagenesis during an interval 1 to $1.5 \mathrm{~m}$.y. after the formation of its crust. We did not recover sediments that had undergone alteration by off-axis activity long after they left the ridge crest, so we cannot document the effect that such activity would have in these slowly deposited, oxidized sediments. It is clear from the material recovered, however, that such off-axis activity, even if it is widespread, does not result in the contribution of significant quantities of hydrothermal sediment to the bottom waters for dispersal. There is no evidence of an offaxis hydrothermal sediment component.

It is clear that we cannot resolve many important questions about the nature of basalt-seawater interaction without analyzing formation waters from deep within the lithospheric crust. Our experience at Hole 504B demonstrates that the collection of such fluids from boreholes will be very difficult, because present drilling technology entails some contamination of the borehole with drilling muds. These muds react readily with the waters in the borehole and mask the chemical signature of the formation waters and of waters that have reacted with basalt.

\section{ACKNOWLEDGMENTS}

We would like to thank the scientific party of Leg 92 for their patience, humor, enthusiasm, and creativity. Their dedication to our integrated scientific effort made the results of this cruise far greater than the sum of the individual chapters in this Initial Reports volume. In addition, we express our appreciation to D. H. Rea and D. E. Gleason for their patience and thoughtfulness and to A. Schramsburg and G. $\mathrm{H}$. Mumm for their moral support. Portions of this work were supported by NSF Grant OCE 83-15846 to M. Leinen.

\section{REFERENCES}

Ade-Hall, J. M., and Johnson, H. P., 1976. Paleomagnetism of basalts, Leg 34. In Yeats, R. S., Hart, S. R., et al., Init. Repts. DSDP, 34: Washington (U.S. Govt. Printing Office), 513-532.

Anderson, R. N., Hobart, M. G., and Langseth, M. G., 1979. Geothermal convection through oceanic crust and sediments in the Indian Ocean. Science, 204:828.

Anderson, R. N., Langseth, M. G., and Sclater, J. G., 1977. The mechanisms of heat transfer through the floor of the Indian Ocean. $J$. Geophys. Res., 82:3391-4509.

Bender, M. L., 1983. Pore water chemistry of the Mounds Hydrothermal Field, Galapagos Spreading Center: results from Glomar Challenger piston coring. J. Geophys. Res., 88:1049-1056.

Bender, M. L., Hudson, A., Graham, D. W., Barnes, R. O., Leinen, M., and Kahn, D., in press. Diagenesis and convection reflected in pore water chemistry on the western flank of the East Rise, 20 degrees, South. Earth Planet. Sci. Lett.

Berggren, W., Kent, D. V., Flynn, J. J., and Van Couvering, J. A., 1985. Cenozoic geochronology. Geol. Soc. Am. Bull., 96:1407-1418.

Boström, K., 1974. Origin and fate of ferromanganoan active ridge sediments. Stockholm Contrib. Geol., 27:149-241.

Boström, K., Joensuu, O., Valdes, S., and Riera, M., 1972. Geochemical history of South Atlantic Ocean sediments since late Cretaceous. Mar. Geol., 12:85-121.

Boström, K., and Peterson, M. N. A., 1966. The origin of aluminumpoor ferromanganous sediments in the areas of high heat flow on the East Pacific Rise. Mar. Geol., 7:427-447.

Corliss, J., Edmond, J. M., and Gordon, L. I., 1979. Some implications of heat/mass ratios in Galapagos Rift hydrothermal fluids for models of seawater-rock interaction and the formation of oceanic crust. In Talwani, M., et al. (Eds.), Deep Drilling Results in the Atlantic Ocean: Continental Margins and Paleoenvironments (Vol. 3): Washington, D.C. (Am. Geophys. Union) 391-402.

Dasch, E. J., Dymond, J., and Heath, G. R., 1971. Isotopic analysis of metalliferous sediments from the East Pacific Rise. Earth Planet. Sci. Lett., 13:175-180.

Delaney, M. L., 1982. $\mathrm{Li} / \mathrm{Ca}$ in foram tests: chemical diagenesis and reconstructing the oceanic record. EOS, Trans. Am. Geophys. Union, 63:353.

Dymond, J., 1981. Geochemistry of Nazca Plate surface sediments: an evaluation of hydrothermal, biogenic, detrital, and hydrogenous sources. In Kulm, V., Dymond, J., Dasch, E. J., and Hussong, D. (Eds.), Nazca Plate: Crustal Formation and Andean Convergence. Mem. Geol. Soc. Am., 154:133-174.

Dymond, J., Corliss, J. B., Heath, G. R., Field, C. W., Dasch, E. J., and Veeh, H. H., 1973. Origin of metalliferous sediments from the Pacific Ocean. Geol. Soc. Am. Bull., 84:3355-3372.

Dymond, J., and Eklund, W., 1978. A microprobe study of metalliferous sediment components. Earth Planet. Sci. Lett., 40:243-251.

Edmond, J. M., Measures, C., McDuff, R. E., Chan, L. H., Collier, R., Grant, B., Gordon, L. I., and Corliss, J. B., 1979. Ridge crest hydrothermal activity and the balances of the major and minor el- 
ements in the ocean: the Galapagos data. Earth Planet. Sci. Lett., 46:1-18.

Elderfield, H., and Greaves, M. J., 1981. Negative cerium anomalies in the rare earth element patterns of oceanic ferromanganese nodules. Earth Planet. Sci. Lett., 55:163-170.

Graham, D. W., Bender, M. L., Williams, D. F., and Keigwin, L. D., Jr., 1982. Strontium-calcium ratios in Cenozoic planktonic foraminifera. Geochem. Cosmochim. Acta, 46:1937-1947.

Handschumacher, D. W., 1976. Post-Eocene plate tectonics, of the Eastern Pacific. In Sutton, G. H., Manghnani, M. H., and Moberly, R. (Eds.), The Geophysics of the Pacific Ocean Basin and its Margin. Monogr. Am. Geophys. Union, 19:177-202.

Haq, B. U., 1984. Jurassic to Recent nannofossil biochronology: an update. In Haq, B. U. (Ed.), Nannofossil Biostratigraphy. Benchmark Pap. Geol., 78:358-378.

Harland, W. B., Cox, A. V., Llewellyn, P. G., Pickton, C. A. G., Smith, A. G., and Walters, R., 1982. A Geologic Time Scale: Cambridge (Cambridge Univ. Press).

Heath, G. R., and Dymond, J., 1977. Genesis and transformation of metalliferous sediments from the East Pacific Rise, Bauer Deep, and northern Nazca Plate. Geol. Soc. Am. Bull., 88:723-733. 1981. Metalliferous-sediment deposition in time and space: East Pacific Rise and Bauer Basin, northern Nazca Plate. In Kulm, L. D., Dymond, J., Dasch, E. J., and Hussong, D. (Eds.), Nazca Plate: Crustal Formation and Andean Convergence. Mem. Geol. Soc. Am., 154:175-197.

Herron, E., 1972. Sea-floor spreading and the Cenozoic history of the east-central Pacific. Geol. Soc. Am. Bull., 83:1671-1692.

Hey, R., 1977. Tectonic evolution of the Cocos-Nazca spreading center. Geol. Soc. Am. Bull., 88:1404-1420.

Kennett, J. P., McBirney, A. R., and Thunell, R. C., 1977. Episodes of Cenozoic volcanism in the circum-Pacific region. J. Volcanol. Geotherm. Res., 2:145-163.

Leinen, M., 1981. Metal-rich basal sediments from northeastern Pacific Deep Sea Drilling Project sites. In Yeats, R. S., Haq, B. U., et al., Init. Repts. DSDP, 63: Washington (U.S. Govt. Printing Office), 667-676.

Leinen, M., and Stakes, D., 1979. Metal accumulation rates in the central equatorial Pacific during Cenozoic time. Geol. Soc. Am. Bull., 90:357-375.

Lyle, M., 1981. Formation and growth of ferromanganese oxides on the Nazca Plate. In Kulm, L. D., Dymond, J., Dasch, E. J., and Hussong, D. (Eds.), Nazca Plate: Crustal Formation and Andean Convergence. Mem. Geol. Soc. Am., 154:269-293.

McMurtry, G. M., Veeh, H. H., and Moser, C., 1981. Sediment accumulation rate patterns on the northwest Nazca Plate. In Kulm, L. D., Dymond, J., Dasch, E. J., and Hussong, D. (Eds.), Nazca Plate: Crustal Formation and Andean Convergence. Mem. Geol. Soc. Am., 154:211-249.

Mammerickx, J., Herron, E., and Dorman, L., 1980. Evidence for two fossil spreading ridges in the southeast Pacific. Geol. Soc. Am. Bull. (Pt. I), 91:263-271.
Maris, C. R. P., Bender, M. L., Leinen, M., and Froehlich, P. N., in press. Chemical evidence for pore water advection in Mariana Trough sediments. J. Geophys. Res.

Ness, G., Levi, S., and Couch, R., 1980. Marine magnetic anomaly timescales for the Cenozoic and Late Cretaceous: a précis, critique, and synthesis. Rev. Geophys. Space Phys., 18:753-770.

Newmark, R., Zoback, M. D., and Anderson, R. N., 1984. Orientation of in situ stresses in oceanic crust. Nature, 311:424-428.

Owen, R. M., and Rea, D. K., 1985. Sea-floor hydrothermal activity links climate to tectonics: the Eocene carbon dioxide greenhouse. Science, 277:166-169.

Quilty, P. G., Sachs, H., Benson, W. E., Vallier, T., and Blechschmidt, G., 1976. Sedimentologic history, Leg 34 Deep Sea Drilling Project. In Yeats, R. S., Hart, S. R., et al., Init. Repts. DSDP, 34: Washington (U.S. Govt. Printing Office), 779-794.

Rea, D. K., 1978a. Evolution of the East Pacific Rise between $3^{\circ} \mathrm{S}$ and $13^{\circ} \mathrm{S}$ since the middle Miocene. Geophys. Res. Lett., 5:561-564. 1978b. Asymmetric sea-floor spreading and a non-transform axis offset: The East Pacific Rise $20^{\circ} \mathrm{S}$ survey area. Geol. Soc. Am. Bull., 89:836-844.

1981. Tectonics of the Nazca-Pacific divergence plate boundary. In Kulm, L. D., Dymond, J., Dasch, E. J., and Hussong, D. M. (Eds.), Nazca Plate: Crustal Formation and Andean Convergence. Mem. Geol. Soc. Am., 154:27-62.

Rea, D. K., Leinen, M., and Janecek, T. R., 1985. Geologic approach to the long-term history of atmospheric circulation. Science, 227: 721-725.

Rea, D. K., and Scheidegger, K. F., 1979. Eastern Pacific spreading rate fluctuation and its relation to Pacific area volcanic episodes $J$. Volcanol. Geotherm. Res., 5:135-148.

Rona, P. A., Boström, K., Laubier, L., and Smith, K. L., Jr. (Eds.), 1984. Hydrothermal Processes at Seafloor Spreading Centers (NATO Conf. Ser., Ser. IV, Vol. 12): New York (Plenum Press).

Seyfried, W. R., and Bischoff, J. L., 1979. Low temperature basalt alteration by seawater: an experimental study at $70^{\circ} \mathrm{C}$ and $150^{\circ} \mathrm{C}$. Geochim. Cosmochim. Acta, 43:1937-1947.

Seyfried, W. R., Janecky, D. R., and Mottl, M. J., 1984. Alteration of the oceanic crust: implications for geochemical cycles of lithium and boron. Geochim. Cosmochim. Acta, 48:557-569.

von Damm, K. L., Grant, B., and Edmond, J. M., 1983. Preliminary report on the chemistry of hydrothermal solutions at $21^{\circ} \mathrm{N}$ East Pacific Rise. In Rona, P. A., Boström, K., Laubier, L., and Smith, K. L. (Eds.), Hydrothermal Processes at Seafloor Spreading Centers: New York (Plenum Press), pp. 369-389.

Weiss, R. F., 1977. Hydrothermal manganese in the deep sea: scavenging residence time and $\mathrm{Mn} / 3-\mathrm{He}$ relationships. Earth Planet. Sci. Lett., 37:257-262.

Date of Initial Receipt: 24 January 1985 Date of Acceptance: 13 May 1985 